\title{
REFUGEES AND ASYLUM SEEKERS, THE CRISIS IN EUROPE AND THE FUTURE OF POLICY
}

\author{
By \\ Timothy J. Hatton \\ (University of Essex, UK)
}

\begin{abstract}
August 2016
ABSTRACT

The recent asylum crisis has thrown into sharp relief the inadequacies of European asylum policies and has highlighted the need for reform. The existing asylum system, which encourages migrants to make hazardous maritime or overland crossings to gain access to an uncertain prospect of obtaining refugee status, is inefficient, poorly targeted and lacks public support. In the long run it should be replaced by a substantial joint programme of refugee resettlement that would help those most in need of protection, that would eliminate the risks to refugees, and that would command more widespread public support. These arguments are built upon an analysis of key facts and data. This includes estimation of the origin and destination factors that influence asylum applications, and the effects of asylum policies adopted in developed countries. It also includes an examination of different aspects of public opinion that condition the scope for the development of asylum policies. In this light I evaluate the feasibility of three elements for reform: first, tougher border controls to reduce unauthorised entry by prospective asylum applicants; second, promoting direct resettlement of refugees from countries of first asylum; and third, expanding refugee-hosting capacity through enhanced burden-sharing among destination countries.
\end{abstract}

JEL codes: F22, F53, J15.

Acknowledgements: I am grateful to Alessandra Venturini and Jennifer Hunt for comments on an earlier draft and to conference participants at the Fondazione Rodolfo DeBenedetti, Milan, the International Migration Institute, Oxford, and the European University Institute, Florence. Thanks are due to the editor of Economic Policy and four referees for constructive comments and useful advice. I am also grateful to Jean-Paul Cassarino for sharing his data on readmission agreements.

Note: This paper is the Panel Draft for a special issue of Economic Policy on the European migration crisis.

\section{Contact:}

Tim Hatton

Department of Economics

University of Essex

Colchester CO4 3SQ

Email: hatton@essex.ac.uk 


\section{Introduction}

The Syrian exodus created a crisis that has thrown the existing European asylum system into chaos and has led to an increasingly polarised debate over extemporised solutions. It has thrown into sharp relief the inadequacies of the existing system and has highlighted the need for reform. The existing asylum system, which encourages migrants to make hazardous maritime or overland crossings to gain access to an uncertain prospect of obtaining refugee status, is inefficient, poorly targeted and lacks public support. In this paper I outline some key facts relating to trends in asylum applications and policy. I also report some econometric results on determinants of asylum applications and the effects of asylum policies in countries of arrival. In order to provide a background to what policy reforms might be feasible I examine several important features of public opinion in Europe and trends over the last decade. This leads to three key areas that should be the principal focus of reforms. These are: border control policies, programmes for resettling refugees who are in the greatest need of protection, and enhanced cooperation and burden sharing among European countries.

A number of conclusions follow from this analysis. One is that, contrary to some views, asylum policies have had an important influence on the volume of asylum applications, especially those relating to border control. Second, while public opinion is increasingly positive towards genuine refugees, it is very negative towards illegal immigrants. This suggests that an asylum policy that encourages migrants to make hazardous maritime or overland crossings to gain unauthorised entry in order to claim asylum will not command public support. This is especially so as a large proportion of those that apply for asylum fail to gain recognition and often remain as illegal immigrants. Existing policies are also poorly targeted: they select those that have the energy, enterprise and resources to risk drowning at sea or falling into the hands of unscrupulous people smugglers, and not necessarily those that are most in need of humanitarian protection.

Direct resettlement of refugees from often dire circumstances in countries of first asylum would be better targeted but would require a substantial increase in the number of places offered for resettlement. That would require the further development of cooperative burden-sharing among host countries. Notwithstanding the resistance of some governments, there is surprisingly strong public support for joint policy at the EU level. Finally, while the current crisis has acted as a spur to the rapid extemporisation of policy, the ongoing, migration pressures have made it more difficult to expand the opportunities for resettlement. Nevertheless the long term aim should be to shift away from 'spontaneous' asylum seeking towards a comprehensive resettlement programme.

\section{Refugees and Asylum Seekers}

\section{Long run trends}

The migration crisis that has gripped Europe in the last few years has focused attention on the predicament of refugees. This is not new. Every year hundreds of thousands of people flee from their country of origin or residence, seeking sanctuary in a safer place. Refugees are defined 
by the 1951 Refugee Convention as persons who have been displaced from their country of origin owing to a "well-founded fear of persecution". Figure 1 shows the worldwide stock of refugees as recorded by the United Nations Commissioner for Refugees (UNHCR) from 1982 to the present. The number rose to a peak of 18 million in 1992 and then declined until 2005. Over the last decade it has increased, at first slowly and then more rapidly, to reach 16 million in 2015. It is worth noting that refugees are only a fraction of the worldwide total of forcibly displaced people, estimated by the UNHCR at 65.3 million at the end of 2015. This total includes asylum seekers, stateless persons, returned refugees, and above all, 37.5 million people who are internally displaced within the borders of their home country.

Asylum seekers are those who apply for refugee status in another country. Figure 1 shows the number of asylum applications lodged in 38 "industrialized" countries (an annual flow rather than a stock), which is a much smaller number (right scale). These are composed overwhelmingly of applicants who have reached a destination country by independent means and then applied individually for asylum rather than having been resettled from camps as part of a resettlement programme. As such, they are sometimes referred to as 'spontaneous' asylum seekers, and while in transit or on arrival, just as migrants. Asylum applications ascended to a peak of over 800,000 in 1992 , followed by a lower peak in the early 2000 s and then a steep surge to double the previous peak in 2015. The figure also shows the number of claims that were lodged in European countries. It illustrates the concentration on Europe which accounts for 78 percent of applications over the whole period, and especially on the EU-15, which accounts for 71 percent of the 38-country total.

The very sharp increase in asylum applications from the mid-1980s was associated with the fall of the Berlin Wall and the dissolution of the Soviet Union which, by opening borders between Eastern and Western Europe, generated asylum flows from these countries as well as opening transit routes for those from more distant countries. While there was something of a backlash in the form of tougher asylum policies, it is notable that the numbers seeking asylum never returned to the levels of the early 1980s. The last few years show a similar steep increase (but from a higher base), far surpassing the 1992 peak to reach 1.6 million in 2015. The sudden surge of asylum seekers accompanied by a partial collapse of border controls invites comparison with the events of twenty years earlier. In particular the flow of asylum applications increased relative to the stock of refugees. This might be seen as another 'paradigm shift' (UNHCR 2015, p. 3), but it is far from clear, as yet, whether this discrete upward step will result in a permanently higher level of asylum applications.

\section{Countries of origin}

Most asylum applicants originate from poor and middle income countries that systematically persecute minorities, or in which human rights abuses are commonplace, some of which are also in the grip of civil wars or international conflicts. Table 1 shows the 20 origin countries with the largest number of applicants to EU countries in 2006-10 and in 2011-15. These account for 65 percent of all applications lodged in the EU in 2006-10 and 85 percent in 201115. It is worth noting that there are major sources of asylum applications from countries in Asia, Africa and from Europe but, in terms of media coverage and public debate, some are 
more obvious than others. As might have been expected the Middle East is a prominent source, as represented by Iraq, Iran, Syria and Turkey, but Russia, Serbia and Georgia are also major sources throughout the decade. The most important African source countries are Nigeria, the Democratic Republic of Congo and Somalia, while prominent Asian sources include Afghanistan, Pakistan, Bangladesh and Sri Lanka. Countries with large populations such as India and China also appear on the list for 2006-10, even though the number of applications is small relative to the source population. It is also worth noting the persistence over time in the sources of asylum claims. Of the top 20 origins for 2011-15 14 also appear in the top 20 for 2006-10. Indeed, all of the top 20 in 2011-15, appear in the top 30 for 2006-10 and 18 appear in the top 30 as far back as 1995-9 (UNHCR, 2001, p, 138). To a large degree this reflects long-standing conflicts, political instability and ethnic divisions (Fearon and Laitin 2012; Besley and Reynal-Querol 2014). Thus, the ups and downs over time in the number of applications are largely driven by variations in the volume of applications from a set of around 50 source countries rather than by countries entering or leaving the list.

Figure 2 shows the variations over the last decade in the number of applicants from the countries that were in the top ten origins in 2011-15 It illustrates the surges in applications associated with civil war and terror as in Iraq in 2006-9 and in Somalia in 2007-10. Most dramatic is the steep upward trend in applications from Syria which reached an unprecedented 363,000 in 2015 (off the graph). But there are also steep increases in applications from Afghanistan, Iraq, Eritrea, Serbia, and to a lesser extent Iran, Pakistan and Nigeria. While the increased intensity of conflict is only too obvious an explanation for the surge of asylum applicants from Middle Eastern countries, and also Eritrea, this is less obvious for some of the other countries. Some countries are both receivers and senders of asylum applicants, as for example Russia, which in 2014 experienced a surge of applications from eastern Ukraine.

In recent years unauthorised migrants travelling by sea have attracted most of the attention. Many, but not all of these intended to apply for asylum. In 20151.8 million migrants crossed the Mediterranean and the Aegean - six times the number in the previous year and twelve times the number in 2008. Until recently the main form of entry was by air with a valid visitor visa but the spread of visa restrictions and electronic tracking have restricted these possibilities. Travel by land and sea to gain entry to the country where an asylum claim is lodged is often achieved with the assistance of people smugglers. Many asylum seekers travel in stages, on well-established routes, often through a series of transit countries. As noted further below, the predominant entry routes have shifted, partly due to the changing composition of migrants by origin and partly in response to increased border security measures. The increased risks in transit may be one reason why the share of asylum applicants accompanied by dependents has fallen steeply since the 1990s. Among those that applied for asylum in the EU in 2014 two thirds were male (Eurostat, 2015). 54 percent were aged 18-34 and of those nearly 80 percent were male. More than a quarter were under 18 and among those about a fifth were unaccompanied minors. The upward trend in the number of unaccompanied minors, some of whom were sent ahead by their families to establish a claim to asylum, is one of the issues of greatest concern (Frontex 2010). 


\section{Destination countries}

Asylum applications are distributed unevenly across different destinations. Table 2 shows the average annual number of asylum applications to EU countries plus Norway and Switzerland by five-year periods since 2001 . The 30 -country total shows that, after falling to about a quarter of a million in the late 2000s, applications increased to nearly 600,000 per annum in 2011-15. Nearly 90 percent of applications are accounted for by the EU-15 plus Norway and Switzerland. In 2011-15 the top five destination countries accounted for nearly two-thirds of all applications with Germany alone accounting for 28 percent. Applications to most of the major destinations declined between 2001-5 and 2006-10, but some such as Italy and Greece experienced increases. And while the last five years saw increases in most countries this was less marked in countries such as Britain and Ireland. Some of the Eastern European countries that were origins of asylum applications in the 1980s and 1990s subsequently became destinations. Some of them saw a decline in the numbers after joining the EU while Hungary and Poland have seen an increase. These periodic fluctuations reflect a variety of influences that are explored in more detail below.

Asylum claims are entered into a process to determine whether the individual qualifies for recognition either as a refugee either according to the definition in the Convention or is accorded protection on other humanitarian grounds. ${ }^{1}$ A large proportion of those that apply for asylum fail to gain some form of recognition. Figure 3 plots the overall recognition rate for 20 European countries from 1982 to 2015 . The Convention recognition rate fell from over half in 1982 to just 7 percent in 1992 while the total recognition rate (Convention plus humanitarian) fell to 17 percent. Recognition rates rose sharply in the 1990s with the total recognition rate reaching a peak of 45 percent at the time of the Kosovo crisis. Recognition rates then fell to the mid-2000s before rising back to a half by 2014. One obvious reason is the increasing number of Syrians for whom the EU total recognition rate in 2014 was 95 percent. ${ }^{2}$ But over the entire period since 1982 the total recognition rate averaged less than one third. As these are first instance decisions they do not take account of successful appeals which would raise the share gaining some form of acceptance by about 10 percentage points. ${ }^{3}$ Nevertheless a large proportion of claims end in rejection and the applicants are required to leave the country either voluntarily, with or without assistance, or by deportation. Nevertheless, a significant but unknown proportion remain in the country as illegal immigrants. ${ }^{4}$

\footnotetext{
${ }^{1}$ Some of those who fail to qualify under the Convention definition of a refugee are nevertheless allowed to remain (often on a temporary basis) because they are judged likely to risk serious harm if returned to their origin country, as provided by the non-refoulement clause (see below).

${ }^{2}$ Other origin countries with high recognition rates in 2014 (with percentages) include Afghanistan (63), Eritrea (89), Iraq (71), Somalia (68) and Iran (60). The recognition rate for stateless persons was 88 percent (see Eurostat 2015).

${ }^{3}$ In the UK over the period 2007-15, 68 percent of applications were rejected in the first instance of which 53 percent were appealed and 26 percent were successful (UK Home Office, 2016, Tables as2 and as14).

${ }^{4}$ Eurostat figures show that, for the EU-28 in 2014, 470,080 individuals were ordered to leave, while only 196,280 departures were recorded. But (a) voluntary returns are (probably substantially) under-recorded and (b) only a proportion of those ordered to leave would have been asylum applicants whose claims were rejected.
} 
Those that are recognised with some form of protection form a growing stock of refugees in the countries that receive the most applications. Table 3 shows that in 2015 seven developed countries were each hosting more than 100,000 refugees. In per capita terms, Sweden stands out with 17.5 per thousand followed by Norway, Switzerland and Austria. The fifteen countries listed in the left hand panel account for 1.8 million or about 12 percent of the world-wide stock of refugees as recorded by the UNHCR. By contrast the list of less developed countries in the right hand panel account for 70 percent of the total. Indeed, 86 percent of all refugees are hosted in poor and middle-income countries of first asylum, often just across the border from the origin country. Within these countries, about 30 percent of refugees are located in refugee camps, often in desperate circumstances. In 2015 Turkey topped the list with 2.5 million, even after many had departed for Europe. But the countries that have the most refugees per capita are Lebanon and Jordan, and twelve out of the fifteen have more than seven refugees per thousand of the population. Even more striking are the numbers in the last column, which shows refugees per million dollars of total GDP (in US 2010 dollars). Nine of the countries have more than ten refugees per million dollars and Chad, Jordan, Lebanon, Uganda, Afghanistan and Ethiopia all have more than 20 per million dollars. By contrast, the left hand panel shows that among the developed countries only Sweden hosts more than one third of a refugee per million dollars. These figures simply underline the well-known fact that the heaviest refugee burdens are borne by some of the poorest countries.

\section{Trends in Asylum Policy}

The foundation of asylum policies is the 1951 Refugee Convention of which all developed countries and most of the rest of the world are signatories. The Refugee Convention has three key provisions. The first is the definition of a refugee (Article 1) which as noted above is a person who is outside their country of normal residence and has a "well-founded fear of persecution." Thus the determination of refugee status must be made on a case-by-case basis in the light of available evidence. The second is the non-refoulement clause (Article 33.1), which requires that an applicant for asylum cannot be returned to the frontiers of a territory where his/her life or freedom would be threatened. ${ }^{6}$ In practice this means that some applicants cannot be sent back even if they fail to qualify for refugee status, and this has provided one basis for subsidiary forms of protection. This clause could operate beyond the destination country's border but in practice it is usually only invoked when an asylum applicant is present on the territory or at the border. The third is that unauthorised entry into, or presence in, the country does not bar admission to the procedure for determining refugee status, nor does it prejudice the outcome of that process (Article 31).

\footnotetext{
${ }^{5}$ The full definition of a refugee in Article 1 of the Convention is a person who "owing to well-founded fear of being persecuted for reasons of race, religion, nationality, membership of a particular social group or political opinion, is outside the country of his nationality and is unable or, owing to such fear, is unwilling to avail himself of the protection of that country; or who, not having a nationality and being outside the country of his former habitual residence as a result of such events, is unable or, owing to such fear, is unwilling to return to it." For the full text see: http://www.unhcr.org/3b66c2aa10.html.

${ }^{6}$ The provisions of Article 1 and Article 33(1) of the Convention are reasserted in the 2001 Charter of Fundamental Rights of the European Union.
} 
In principle there is no limit to the number of applications that a state is liable to accept and each application must be accorded due process. And although the Convention does not provide the right to permanent residence, it does encourage signatory states to "facilitate the assimilation and naturalization of refugees" (Article 34). However the Convention was conceived in circumstances very different from today and it did not provide a detailed set of rules for dealing with a mass influx of asylum seekers arriving on the territory. As a result it left open numerous ways in which receiving countries could act to deter asylum applications. Principal among these are stiffer border controls and tougher status determination procedures.

\section{The development of asylum policies}

From the late 1980s the developed countries of the EU, North America and Australasia progressively tightened their asylum policies. In the United States and Canada policy was tightened in response to attacks of $9^{\text {th }}$ September 2001. The USA PATRIOT Act radically increased the number of border patrol officers and their power to detain those suspected of terrorist offences. This was followed in 2002 by a further Act that introduced a new visa system with an integrated database system linked to fingerprinting and biometric monitoring. In parallel, Canada also increased its border security with reforms that included detention of asylum seekers without documents. In Australia the 9/11 effect was upstaged by a rising number of boat arrivals and this triggered a raft of legislation to limit access and to toughen asylum procedures that became known as the 'Pacific Strategy' (see Box 1 below). In 2008 Australia eased some elements of this policy only to reverse it again in 2013. In 2012 Canada also reformed its status determination procedures with fast track processing for those from evidently safe countries of origin and prompt removal of failed claimants.

In the EU the steep increase in asylum applications from the late 1980s, chiefly from Eastern Europe, triggered asylum reforms in several countries. In Germany this involved a revision of the Basic Law (constitution) in 1993 in order to restrict manifestly unfounded asylum applications and asylum seekers entering from safe third countries or from safe countries of origin (Hailbronner, 1994). Similar steps were taken in other countries. In Denmark the Aliens Act of 1983 was amended to become more restrictive in 1995 and again in 1998. In 2002 the right to asylum on humanitarian grounds (for those not qualifying under the Convention) was scrapped and social benefits for refugees were cut. In the UK, a fast-track procedure for applicants from safe countries of origin was introduced in 1993 and the safe third country concept was introduced in 1996. The Immigration and Asylum Act of 1999 created the National Asylum Support Service under which asylum seekers were dispersed to reception centres outside London and vouchers were substituted for welfare benefits.

A similar course was followed in other European countries, sometimes in large legislative packages but often as an incremental process. In the Netherlands a range of new border controls were introduced in 1998 and in 2001 legislation was passed to restrict the scope of subsidiary protection and to limit the right of appeal. This was followed by the reorganisation of the asylum administration under a new ministry with the aim of speeding up the processing of applications and tougher enforcement of deportation procedure for unsuccessful claimants. Other EU countries toughened the processing of manifestly unfounded claims. One example is 
Austria which in 2004, restricted the right to apply at the border and reduced processing times for manifestly unfounded applications to three days, making appeals non-suspensive of deportation. But not all policy change was restrictive. A number of countries introduced more extensive integration policies and some, such as Finland in 2006 and Germany in 2007, increased access to employment for asylum applicants. Perhaps the most striking case is Sweden, which in 2006 widened the criteria for qualification for Convention recognition and subsidiary protection as well as the basis for appeals. Then in 2009 Sweden allowed work permits to some failed asylum seekers; in 2010 it allowed asylum applications through consulates abroad; in 2011 it relaxed visa requirements from the Western Balkans; and in 2013 it provided permanent residence for Syrians.

\section{The Common European Asylum System}

Until the end of the 1990s asylum policies were not directly coordinated between EU countries. But the 1990 Dublin agreement over which EU country would take responsibility for an asylum claim and the resolutions of a ministerial meeting in London in 1992 on the concepts of 'safe third country' and 'safe country of origin' set the pattern for measures that were later adopted by individual countries in light of trends in the number of applicants, political pressures and developments elsewhere (Hatton 2004). A round of policy tightening in the early 2000s was followed by policy easing in some countries. With the Treaty of Amsterdam, which came into force in 1999, asylum policy shifted to from the third pillar (intergovernmental cooperation) to the first pillar (community integration). ${ }^{7}$ From that time the EU set a course to build a Common European Asylum System (CEAS). This proceeded in three stages named after the cities in which policies were agreed; these are the Tampere programme of 1999-2004, the Hague programme of 2004-9, and the Stockholm programme of 2009-14.

The main focus was on harmonising the conditions for access to asylum procedures, the procedures for processing asylum applications and the rights and conditions afforded to asylums seekers. In the initial stages of the programme four key directives were issued. The Dublin II regulation (2003) revised the mechanism for determining the state responsible for an asylum claim and for inter-country transfers. The Qualification Directive (2004) provided a common set of criteria to be used in the procedure to determine refugee status. The Asylum Procedures Directive (2005) covered issues such as which claims could be treated as manifestly unfounded, the rights of applicants to legal assistance and appeals, and the rules for granting subsidiary protection. And the Reception Conditions Directive (2003) laid down minimum standards during the processing of applications for access to employment and training, housing and subsistence, and health and education services. ${ }^{8}$ It is important to stress however that these (and other directives) did not cover every aspect of asylum policy and they were minimum standards, which were below the standards prevailing in some countries and therefore not necessarily binding. This left some room for countries to adjust their policies, depending on the initial policy stance. Thus while the first stage of the CEAS fell far short of complete

\footnotetext{
${ }^{7}$ This structure was introduced in the 1993 Maastricht Treaty and was abolished by the 2009 Lisbon Treaty.

${ }^{8}$ For more detail on these directives, see http://ec.europa.eu/dgs/home-affairs/what-we-

do/policies/asylum/index_en.htm.
} 
harmonisation it did create some convergence of policy and practice (Thielemann and ElEnany, 2009).

The second and third stages of the CEAS involved a range of measures, the most important of which relate to border control. The Frontex agency was established in 2005 to strengthen control of the EU's external border and provide a standardised border procedure. This also involved integrating the EURODAC fingerprint database, originally established in 2000. Aside from these functions, Frontex has coordinated and led border security operations (Hermes, Poseidon, Rabit) and is now to be replaced by a European Border and Coast Guard with stronger and more independent powers. And from 2008 the EU brokered a series of readmission agreements with origin and transit countries, following a pattern established in the bilateral agreements of member states. ${ }^{9}$ There was also a round of upgrading of existing directives: the Qualification Directive (2011), the Procedure Directive (2013), the Dublin Regulation III (2013) and the Reception Conditions Directive (2013). These typically raised standards but have not yet been transposed into the legislation of most countries.

The sequence of EU directives has been aimed at harmonising standards, procedures and processes. But the volume of asylum applications has remained very uneven across EU member states, both in absolute terms and in relation to the capacity to host refugees. Despite extensive discussion, little progress was made on improving the distribution-so called burden-sharing. The Amsterdam Treaty (Art 63, 2b) aimed at "promoting a balance of effort between member states in receiving and bearing the consequences of receiving refugees and displaced persons". In the aftermath of the Kosovo crisis the European Refugee Fund (ERF) was established to provide a common financial pool to support refugee integration. ${ }^{10}$ This was followed by the Temporary Protection Directive of 2001, the purpose of which was to distribute refugees among member states in the event of a mass influx, again calling for a 'balance of effort'. While this directive provides a basis for burden-sharing, it lacks a formal triggering mechanism or a distribution key. And despite requests from individual member states (Italy, Greece, Malta) it has never been invoked. In 2010 the European Asylum Support Office was established in Malta with the aim of disseminating best-practice methods and supporting states facing exceptional asylum pressures. While the office was also expected to assist in the relocation of recognized refugees, this is only on an agreed basis between member states and with the consent of the individuals concerned. In addition, the revision of the Dublin Regulation took account (at least in principle) of the pressures faced by different countries. Thus, although there have been periodic proposals for some formal system of burden-sharing, the existing provisions that rely on voluntary contributions have been largely ineffective. The recent emergency has made further progress all the more important, and this theme is taken up in section 7 below.

\footnotetext{
${ }^{9}$ These are usually agreements whereby one country agrees to re-admit its nationals (and sometimes third country nationals who have transited through that country) who are residing illegally in the other country (or in any EU country), often as part of a wider reciprocal agreement. Readmission agreements are described and evaluated by Cassarino (2010).

10 The European Refugee Fund was originally established in 2000. For 2008-13 it was allocated €628 million Euros. It was replaced in 2014 by the Asylum, Migration and Integration Fund with an allocation of $€ 3.137$ billion for 2014-20.
} 


\section{Explaining applications for asylum}

Recent experience in the Mediterranean and the Aegean has rekindled the debate over whether those claiming asylum in the West are genuine refugees or simply 'economic migrants' from poor countries seeking a better life. On one hand it is argued that most applicants are from countries embroiled in civil wars and human rights abuse and are therefore likely to have a legitimate claim to asylum. On the other hand it is pointed out that less than half of all applicants are recognised as refugees or otherwise accepted on humanitarian grounds as in need of protection. Hence it is implied that they are migrating mainly for economic reasons. Here I examine the key influences that drive asylum applications.

\section{Existing studies}

A number of studies have examined worldwide displacement focusing on the stock of refugees or changes in the stock. A major theme of these studies is that refugee flights can be understood as depending on the balance between the costs and benefits of leaving as compared with those of staying. The early cross-sectional studies found that the stock of displaced persons could be explained mainly by genocide, civil war, dissident conflicts and political regime transitions (Schmeidl 1997; Davenport et al. 2003; Moore and Shellman 2004). Subsequent research has elaborated on this theme. Moore and Shellman (2006) found that civil war, dissident terror and government violence increases the number of refugees relative to the number of internally displaced. Consistent with this, Melander and Öberg (2007) find that the wider the spread of violence the more likely that it will generate refugees. Moore and Shellman (2007) focus on the direction of refugee flights, finding that refugees move to places that are free of conflict, where incomes are higher and the costs of transit are lower. Melander and Öberg (2006) analyse the persistence of displacements, arguing that the flows tend to decrease when those most able or willing to move have left. They also found that outflows are reduced by regime transition in the origin country but increased by regime collapse. ${ }^{11}$

Several studies have analysed panel data on the flow of asylum applications to the developed world with a particular focus on the effects of asylum policies. Studies by Neumayer (2004) and Thielemann (2006) took as the dependent variable the share for each destination of applicants from each origin country over the 1980s and 1990s. This method nets out common source country effects. Controlling for variables such as the pre-existing stock of immigrants from the origin at the destination, as well as variables representing economic and political conditions at the destination, these studies found some evidence that tougher refugee status determination procedures reduced asylum claims. Analysing applications to EU countries over the period 1981-99, I found that an index of policy had a significant deterrent effect in the presence of variables representing conditions in both origin and destination countries (Hatton 2004). In a later study I examined the effects of policy on panel data for asylum applications from 48 origin countries to 19 destinations from 1997 to 2006 (Hatton 2009). The overall effect

\footnotetext{
${ }^{11}$ A second generation of studies analyses the complexities of displacement at the local and individual levels, see Adhikari (2012) for Nepal, Engel and Ibáñez (2007) and Steele (2009) for Columbia, and Alvarado and Massey for four other Latin American countries.
} 
of the round of policy tightening between 2001 and 2006 was to reduce annual asylum applications to the 19 countries by 108,000 or about one third of the total decrease.

\section{Model and data}

Here I analyse annual asylum applications to 19 destination countries from 48 origin countries over the years 1997 to 2014. The destinations include 16 European countries plus Australia, Canada and the United States, which together account for 91 percent of the total flow of asylum applications to industrialised countries in the last two decades. The origin countries are those that have generated the largest numbers of asylum applications since 2000, accounting for about four fifths of the flow to all developed countries. The asylum applications are taken from the data provided by the UNHCR in its annual reports and its online database. The particular destination-origin dyads that are included in this analysis are those for which there were least 300 applications over the years 2000-12. This avoids cases in which there are a large number of dyad-years where the number of applications is zero, and it leaves 626 destination-source country pairs out of a possible $48 \times 19=912$ dyads. In addition some observations are lost because of missing data, notably for the years 1997-9, so that the average number of observations per dyad is 17.4 .

The explanatory variables are those that have been widely used in previous studies. The intensity of terror and human rights abuse is represented by the Political Terror Scale, an index ranging from 1 (no terror) to 5 (high terror). Also included are the Freedom House indexes of civil liberties and political rights, which range from 1 (complete freedom) to 7 (freedom highly restricted). While these variables are often associated with various types of violence I also include a measure of outright war: the number of battle deaths on the origin country's territory as a share of its population, taken from the Uppsala Conflict Data Program. Overall living standards for both origin and destination countries is represented by real GDP per capita from the Penn World Tables (extended to 2014 with data from the IMF). For destination countries, employment possibilities are represented by the OECD's harmonised unemployment rate for all workers. In order to capture the 'friends and relatives effect' that is well known in the migration literature I use the stock of migrants from each origin country living at each destination in 2001. This is taken from the most recent version of dataset assembled by Docquier and Marfouk (2006), which counts adults aged 25 and over. The sources and definitions of these variables are listed in the Appendix 1.

In order to assess the deterrent effects of policy on the number of asylum applications we need an index of asylum policy. Asylum policy is a diverse mixture of incentives and rationing and it contrasts with, for example, international trade, for which the most obvious policy instrument, a tariff, is a single index with a directly measurable value. For asylum policy (as with immigration policy) we have to resort to crude proxies to capture its various different features (for a critical review of such measures see Czaika and de Haas, 2013). Here I use an index of policy updated to 2014 from Hatton and Moloney (2015). It includes indicators for fifteen different dimensions of asylum policy, which can be divided into three groups (each of five components). The first is policies that, one way or another, prevent or deter potential asylum seekers from reaching a country's border, thus limiting access to its asylum procedures. 
The second attempts to capture the likelihood that an applicant gains some form of recognition. And the third includes various policies that relate to the individuals welfare during and immediately after processing.

The fifteen components of the index are listed in Table 4. They are divided into three groups relating to access to the territory, the processing of asylum applications, and the welfare conditions of applicants during processing. Starting at zero in the first quarter of 1997, each component increases by one if policy changes in a way that is expected to adversely affect an asylum applicant, or decreases by one for a favourable change. The index is intended to measure 'major' changes in policy - those that represent significant shifts in the conditions facing a substantial share of asylum seekers. Such judgements are inevitably subjective but they are based on summaries of legislation and secondary reports by experts rather than on general impressions of the toughness of asylum policies. One strength is that they are based on accounts published at the time that legislation was passed, or when new rules were introduced, rather than on ex-post evaluations made in the light of the apparent results of policy. And, as far as possible, the policy change is allocated to nearest quarter of a year when the policy came into effect. I also examine three other policy-related variables. One is the share of applicants that are accepted as refugees or on other humanitarian grounds (the total recognition rate). Another is a dummy variable for the existence of a readmission agreement between a destination country and an origin country (a bilateral variable). And the third is an index of the destination country's policy on immigration for employment, in order to test for possible substitution between migration channels. The sources and definitions of these variables are reported in Appendix 1.

\section{Econometric results}

The key drivers of asylum applications are explored in Table 5. The dependent variable is the $\log$ of the ratio of applications from an origin to a destination (plus one to account for zeros) to origin country population. In the first column there are origin fixed effects and a dummy variable for each destination (not shown). There is some evidence of an upward trend in asylum applications of about 5 percent per annum that is not accounted for by the other variables in the model. The second column includes a dummy variable for each year, which absorbs common trends, but has very little effect on the other coefficients. In the first two columns the coefficient on the log of the ratio of the migrant stock from an origin at a destination to the origin population (in 2000/1) is highly significant. This illustrates the power of the 'friends and relatives effect', which is found in most studies of the determinants of migration. It is usually interpreted to represent the effect of cultural and historic ties as well as the attraction of joining expatriate communities and the information and assistance that they provide. The coefficient implies that a ten percent increase in the stock of immigrants would increase the flow of asylum applications by 2.3 percent. The effect of the log of distance between origin and destination capital cities is negative and significant, even in the presence of the migrant stock. Thus the costs and difficulty of reaching a destination increase with distance in a manner that is not fully reflected in the scale of past migration to the same destination. The gradient is very steep, which may reflect the hazards of clandestine migration over long distances. 
Columns (3) to (5) include fixed effects for every origin-destination dyad and so the effects of the migrant stock and distance, which take only one value for each dyad, are fully absorbed. As the migrant stock and distance account for a large share of the total variation the R-squared is lower in these equations. However, the coefficients on source country variables are little affected. One of the most important is the Political Terror Scale, where an increase of one point on the scale increases the number of applications on the order of 20 percent. Of the two Freedom House indices, that for civil liberties is positive and significant. The coefficient implies that one point on the scale increases asylum applications by around 25 percent. The lack of significance for political rights may be due to the fact that while political repression may increase the incentive to leave, it may also reduce the ability to do so. In the presence of these variables the effect of civil war, as measured by the number of battle deaths per thousand of the population, is not significant. This may be because fleeing civil war does not of itself confer refugee status. The coefficient on origin-country GDP per capita offers some support for the view that adverse economic conditions at home spur asylum migration, even though poverty may also constrain the ability to migrate. A ten percent increase in GDP per capita reduces applications by around five percent.

The upward trend observed in Col. (1) could be explained in several different ways. One hypothesis is that it is due to shrinking the effective distance between the sources of conflict and developed country destinations as communication has improved, and as the possibilities for travel have increased with the deepening of migrant smuggling networks. But the interaction between distance and year in column (4) is not significant. Another hypothesis is that wars have become more important as a source of asylum applications. The positive and highly significant coefficient on the interaction between battle deaths and year offers some support for this hypothesis. However this is entirely the result of the years since the Arab Spring; if the last three years are excluded from the data then z-statistic of the coefficient on the interaction is just 0.01 . Among the destination country variables, the unemployment rate gives a significant negative coefficient while GDP per capita is not significant. The policy index gives a strong negative coefficient, suggesting that tougher policy has a deterrent effect on the number of applications. Finally, the regression in column (5) excludes the three countries outside Europe in order to investigate whether the results depend on their inclusion. Evidently they do not, as the size and significance of the coefficients is little altered.

\section{Exploring policy effects}

The effects of asylum policies are explored further in Table 6, which reports the results of regressions with fixed effects for each origin country by each year. ${ }^{12}$ These fixed effects completely absorb the origin-country variables that appeared in Table 5 and any heterogeneity in their effects. ${ }^{13}$ The result in the first column of Table 6 shows that the coefficients on the

\footnotetext{
${ }^{12}$ If surges in asylum application lead to tougher policy then policy effects would be downward biased. But because of the lengthy political process this is likely to operate with a lag (Hatton, 2004, p. 31).

${ }^{13}$ Under certain assumptions, the use of origin-by-year fixed effects also absorbs any deflection effects between destinations. For a full exposition of models of 'multilateral resistance to migration', see Bertoli and FernándezHuertas Moraga (2013). Barthel and Neumayer (2015) estimate directly the effect of policy spillovers between destination countries, finding it to be small.
} 
bilateral variables and the destination country variables are similar to those in column (2) of Table 5. In the second column of Table 6 the three main components of the policy index are entered separately. The coefficients on policy on access to the territory and on the procedures for processing asylum claims are both significantly negative. A one point increase in these indices reduces applications by 17 and 12 percent respectively. But the coefficient on the index representing welfare conditions for asylum seekers is insignificant. One interpretation of these results is that what matters most to asylum seekers is the probability of gaining permanent settlement. As asylum seekers are willing to undergo enormous hardships in order to get to the destination in the first place, it is perhaps not surprising that the prospect of further privations have little effect.

Some studies include the recognition rate as a measure of the toughness of the refugee status determination process. Column (3) of Table 6 includes the overall recognition rate for asylum claims to each destination country (not separately for each origin). It is lagged by one year to account for possible endogeneity. ${ }^{14}$ The coefficient is positive and significant with surprisingly little effect on the coefficient on asylum processing, to which it is related. One possible reason for the separate effect may be that it reflects changes in administrative practices that are not captured by the policy index. However the effect is modest: a ten percentage point increase in the recognition rate increases asylum applications by 2 percent. Column (4) adds a dummy for whether a readmission agreement was in effect between origin and destination countries. These agreements vary widely but they include an undertaking by the origin country to take back an individual from that country who has been ordered to leave the destination. The coefficient is positive suggesting that readmission agreements are associated with an increase in applications although it is only significant at the ten percent level. One reason may be that these agreements are often part of a package of measures some of which provide some inducement, often visafree travel, to the cooperating country. ${ }^{15}$

Finally, it is sometimes argued that restrictive immigration policies have increased the incentive to use the asylum channel as an alternative route to gain entry to the labour markets of developed countries. In order to test this hypothesis the last column of Table 6 includes an index of the restrictiveness of employment-based immigration policies in destination countries, where higher values represent more restrictive policy. This variable, which is introduced with a lag of one year, takes a positive and marginally significant coefficient. While there may be some degree of substitution, the effect is relatively modest. On average over the period from 1997 to 2014 employment-based immigration policies became less restrictive and so they did not add to the number of applications for asylum. Indeed, the effect is to reduce applications on average by 9 percent.

\footnotetext{
${ }^{14}$ The recognition rate is an outcome of policy, not the policy itself. One source of endogeneity could be that a higher recognition rate might increase the number of applicants for asylum with weaker claims, which would be likely to reduce the recognition rate. When the lagged value in column (3) is replaced by the current value the coefficient becomes negative (' $z$ ' $=2.06$ ).

${ }^{15}$ For a full discussion of policy packages with a readmission component, see Cassarino (2010, 2014). These agreements include provision for the readmission of third country nationals who have transited through the readmitting country. There are some doubts about the effectiveness of such provisions, but any reduction in applications from third country nationals would not be captured in the bilateral flow of applications.
} 
What effect did the key asylum policy variables have on the trends in asylum applications? Figure 4 shows the overall trends in the (unweighted) average of the overall policy index. This increases from zero in 1997 to 3.5 in the mid-2000s after which there is no upward trend in policy restrictiveness until the very end of the period. The initial tightening of policy took place in the aftermath of the surge in asylum applications following the Kosovo crisis and the attacks of September 2001. Figure 4 also shows that each of the three components of the index followed a similar pattern of sharp tightening to the mid-2000s followed by relatively little change. However, at the country level, the extent and timing of changes in policy are far from uniform.

This is illustrated by the effects of policy on asylum applications that are shown in Table 7 Here I use the coefficients on access policy and processing policy from column (2) of Table 6 to calculate the percentage effect of policy on asylum applications from 1997 to 2005 and from 2005 to 2014. From 1997 to 2005 there was severe tightening in a number of countries and the effect was to reduce asylum applications by more than 25 percent in twelve out of the 19 countries and by more than 40 percent in five of them. The weighted average of percentage changes amounts to a reduction of almost 30 percent. If these percentage changes are applied to the mean of total applications for each destination country (not just the 48 origin countries used in the regressions) this implies a reduction of 133,645 in annual asylum applications between 1997 and 2005. Over the period 2005-2014 the changes in policy were more mixed, with policy reducing applications by more than 25 percent in only two countries. On the other hand policy was eased in four countries, most notably in Sweden, which saw a massive loosening of policy. This is the main reason that the weighted average policy effect is positive, and the overall effect for the 19 countries is an increase of 11,107 in annual applications.

\section{Public Opinion}

The recent migration crisis has generated heated debate over refugee policy and immigration policy more broadly. Clearly, governments have to respond to the opinions of the people who elected them. Here I examine three different dimensions of public opinion in Europe.

\section{Opinion on immigrants and refugees}

It is often assumed that public opinion has become increasingly anti-immigration. Negative press coverage of immigration-related events and the rise of far right populist parties seem to point in that direction. Recent evidence suggest that there was some negative shift in public opinion in the recession that followed the global financial crisis but that over the longer run these shifts have not been very large (Hatton, 2016). It worth distinguishing between opinion on refugees and opinion on immigrants in general. While there is a wide range of survey evidence on various aspects of attitudes to immigration there is far less information relating specifically to refugees. However, some comparisons over the longer term are possible using the European Social Survey (ESS).

In 2002 and again in 2014 the ESS included a module on opinion towards immigration. Unfortunately most of the questions differ between the two modules but one of the questions 
on refugees is the same. With the lead-in line that 'Some people come to this country and apply for refugee status on the grounds that they fear persecution in their own country', respondents were asked:

- Please say how much you agree or disagree that: 'the government should be generous in judging people's applications for refugee status' (Agree strongly/agree/neither agree nor disagree/ disagree/disagree strongly).

In each round of the ESS respondents were asked their opinions on government policy on different types of immigrants. Here I examine the questions on immigrants from minority ethnic backgrounds and from poorer countries as these seem to be the most relevant comparisons for refugees. Prefaced by 'Now some questions about people from other countries coming to live in [country]', the questions are:

- To what extent do you think [country] should allow.....people of a different race or ethnic group from most [country] people? (many/some/a few/none).

- How about people from the poorer countries outside Europe? (many/some/a few/ none).

Anti-immigration sentiment is measured by the share of respondents answering 'a few' or 'none' to the latter two questions and the share of respondents either disagreeing on disagreeing strongly with the statement on the treatment of refugees.

Table 8 shows the percentage of respondents expressing anti-immigration opinions in 2014 and the change in percentage points, between 2002 and 2014. For the 14 countries in the table, there is a wide range opinion on admitting immigrants from ethnic groups different from the majority in the country. The change in opinion also varies widely, ranging from an increase in antiimmigration opinion of 19.1 percentage points in the Czech Republic to a decrease in antiimmigration opinion of 20.0 percentage points in Norway. The 18-country average is a decrease in anti-immigrant opinion by 6.3 percentage points. Changes in opinion on immigration from poor countries outside Europe also vary widely, with a distinct hardening of opinion of more than ten percentage points in Switzerland, the Czech Republic, Denmark, Finland, Ireland, Switzerland and the UK. The country average is an increase in antiimmigration opinion of 6.7 percentage points. Despite some differences, the cross-country correlation coefficient of changes opinion across these two questions (18 observations) is strong at 0.85 .

Countries also vary widely in public opinion towards being generous in judging applications for refugee status. On this measure, level of anti-refugee opinion ranges from more than 40 percent of respondents in Belgium, the Czech Republic and the Netherlands to less than ten percent in Poland, Portugal and Sweden. Anti-refugee sentiment has declined in all 18 countries although with varying magnitudes and the country average of these declines is 14.7 percentage points. As a result, negative opinion towards refugees is now in the minority for every country. This contrasts with opinion on immigrants from different ethnic groups and from poor countries. The cross-country correlation between changes in opinion on refugees and changes in opinion on different ethnic groups (cols. 2 and 6) is 0.27 while the correlation between 
opinion on refugees and that on immigrants from poor countries (cols. 4 and 6) is 0.01 . These correlations are much weaker than that between opinion on immigrants from minority ethnic groups and on those from poor countries.

One reason for the diversity of changes in opinion is that European countries have very different experiences with asylum applications, as illustrated in Table 2. In Figure 5 the change in opinion between 2002 and 2014 is plotted against the change in asylum applications per capita in the preceding five years. Anti-immigration opinion on immigrants from minority ethnic groups or those from poor countries is positively correlated with the change in asylum applications $(r=0.36,0.50)$. On the other hand there is a weak negative correlation between asylum applications and the change in opinion on refugees $(-0.17)$. These results are confirmed in regression analysis on individual-level data, which controls for socioeconomic variables that have been found to influence opinion (see Appendix 2). Although an increase in the number of asylum applications is associated with a hardening of opinion towards immigration of ethnic minorities and those from poor countries, it does not seem to have had much effect on attitudes towards genuine refugees. But there are two other key dimensions to public opinion.

\section{The salience of immigration}

First, it is important to make the distinction between opinions on the desirability of more or less immigration and the extent to which immigration is viewed as an important issue for policy (Hatton 2015b). Almost all of the economic analysis of public opinion towards immigration has focused on questions of the 'more or less' variety (sometimes referred to as a Likert scale), or what might be called preference. This does not take into account the weight that the respondent places on immigration as a policy issue, or in other words its salience. Salience is important because of the link to policy. The preferences of voters for more or less immigration will not gain political traction unless salience is sufficiently high to make it a political priority.

One measure of salience is provided by the Eurobarometer surveys of public opinion in EU countries. The survey is conducted bi-annually in spring and autumn of each year, with around 1,800 cases per country/year. Countries outside the EU are not included but the number of countries covered has increased as the EU has expanded. The Eurobarometer surveys vary widely in scope and focus but since 2002 they have included a question relevant to issue salience. This is the response to the question: "What do you think are the two most important issues facing (our country) at the moment?" The respondent is asked to pick two from a menu of 14 political issues, of which immigration is one. The other issues range from crime to the economy to health and education, or the respondent may select one or two other topics that are not on the list. ${ }^{16}$ Because the individual is only able to pick two, this measure captures the importance attached to immigration relative to other policy-related issues. The variable for

\footnotetext{
16 The full list of options is: crime, the economic situation, public transport, rising prices/inflation, taxation, unemployment, terrorism, defence/foreign affairs, housing, immigration, the healthcare system, the education system, pensions, environmental protection, other and don't know. There were two significant changes to the offered list: from September 2006 public transport was replaced by energy-related issues, and from May 2012 defence/foreign affairs was replaced by public debt.
} 
salience is coded 1 if the individual mentions immigration as one of the two most important issues, otherwise zero.

Table 9 shows the proportion of respondents mentioning immigration as one of the two most important issues facing the country in 2003 and every two years from 2007. The proportion is often relatively low but it tends to increase sharply when issues relating to immigration appear in the news or are sparked by political debate. There are also wide variations between countries. Even before the recent refugee crisis, immigration occupied a higher profile in Austria, Belgium, Denmark and the UK than elsewhere. In these countries anti-immigration sentiment is often perceived to be higher than preferences for more or less immigration would suggest. This goes some way to explain why the UK (and its government) is often seen as more antiimmigration than the other countries. Although UK preferences are only slightly more negative than average, salience is consistently much higher than average. ${ }^{17}$

In the recession that followed the global financial crisis the salience of immigration declined as economic issues came to the fore. As Table 9 illustrates, it declined in every country except Greece, and it remained low during the protracted Euro crisis. Multilevel analysis of annual data indicates that this pattern was reversed as the Euro crisis faded, as immigration recovered, and as the consequences Arab Spring unfolded (Hatton 2016). From 2013, as the Syrian crisis escalated and numbers fleeing to Europe by sea and by land surged, the salience of immigration increased sharply. As column (5) shows, by May 2015 (the latest Eurobarometer survey available at the time of writing) the salience of immigration had reached unprecedented heights. It is often suggested that the migration crisis has shifted attitudes strongly against immigration. But this is largely a shift in salience rather than in preferences for more or less immigration.

Political debate (and sometimes action) is activated by the interaction of high salience and negative underlying preferences over immigration. ${ }^{18}$ Thus the increase in salience has the effect of magnifying pre-existing preferences. As one writer observes in the UK context: "public opinion becomes an important factor when the prevailing mood is highly negative and the issue is salient to voters and to the media, forcing policy responses from governing and opposition parties alike" (Ford et al., 2015). The increase in salience may also lead to the polarisation of attitudes as it serves to magnify both positive and negative preferences. ${ }^{19}$ But if, as illustrated in Table 8, preferences over immigration (and especially over refugees) are not overwhelmingly negative then one should not expect a political and policy backlash. However there is one dimension in which preferences are strongly negative-illegal immigration.

\footnotetext{
${ }^{17}$ Freeman (1994) noted that policy seemed to be more closely aligned with preferences in Britain than in other comparable countries and he characterised Britain as a 'deviant case'. But this seems much less of an anomaly when salience is brought into the picture.

18 One way to characterise the interaction of salience and preference over immigration is as arguments of a quadratic loss function (see Wlezian 2005): $U_{i}=-\sum_{k=1}^{n} s_{k i}\left(p_{k i}-v_{k}\right)^{2}$, where total utility loss for individual $i$, $U_{i}$, is the sum over $k \sim 1 \ldots, n$ political issues. For each issue, $k$, the deviation between the individual's preferred value, $p_{k i}$, and the actual value, $v_{k}$, is weighted by the salience of the issue, $s_{k i}$.

${ }^{19}$ Polarisation is also exacerbated by media coverage. For example the coverage of the riots that took place in Cologne of $31^{\text {st }}$ December 2015 and the murder of an attendant in a Swedish reception centre in November fuelled negative attitudes while Angela Merkel's welcome to Syrian migrants provoked some positive reaction. For the US, Facchini et al. (2011) find evidence of a causal link between media reports and public opinion.
} 
Clearly this is important for asylum policy as a large share of recent asylum seekers have entered the destination country without authorisation.

\section{Illegal immigration}

The second dimension is illegal immigration. As we have seen, unauthorised entry has been a key feature of the recent crisis. Survey evidence indicates that respondents are overwhelmingly negative about illegal immigration. Table 10 presents a comparison between concerns about legal and illegal immigration, taken from the Transatlantic Trends survey for 2009, 2011 and 2013. The question is: "Can you tell me if you are worried or not worried about legal immigration?" and the same question is repeated for illegal immigration. In general, the level of concern about illegal immigration is more than double that about legal immigration. Even more strikingly, these concerns increased sharply over the four years from 2009 to 2013, especially those relating to illegal immigration, which increased by around ten percentage points. Unfortunately the same question was not asked in the most recent survey (2014) but it seems likely that the share expressing concerns would have increased further as the migration crisis unfolded. Concerns about legal immigration were highest in UK but the gap between concerns about legal and illegal immigration are largest in Italy and Spain. In these countries, which experienced the greatest pressures of migration across the Mediterranean, concerns over illegal immigration increased by less as they were already high in 2009. Transatlantic Trends covered a larger number of countries in 2013. Concern about illegal immigration was 88.9 percent in Portugal but the percentages were lower in transit countries like Poland (46.2), Romania (46.2) and Slovakia (59.4) as well as in Sweden (59.4).

At the individual level, concerns about both legal and illegal immigration are positively correlated with the opinion that there are too many immigrants and that immigration is more of a problem than an opportunity for the country. As a number of studies have shown antiimmigration attitudes are related to economic and personal insecurity and to other broadly defensive traits (see the surveys by Ceobanu and Escandell, 2010, and Hainmueller and Hopkins, 2014). Such traits are often associated with a lack of trust in public institutions and in government policy. However in Transatlantic Trends the overall correlation across individuals between being worried about illegal immigration and whether the government was doing a poor or very poor job on immigration policy is not particularly strong: 0.06 in 2009 and 0.16 in 2013.

\section{Locus of control over immigration policy}

Given that anti-immigration attitudes are often associated with nationalism and inward looking attitudes in general, one might expect that most people would prefer to see immigration policy controlled by their national government, over which they have direct influence, rather than by a supra-national authority such as the EU. And all the more so, as trust in the EU has diminished since the global financial crisis of 2007. That might be expected to slow the development of the Common European Asylum System that was outlined in section 3 above. The evidence suggests that core support for the EU, which was already weakening, has diminished sharply 
during the recession (Armigeon and Ceka 2014). Yet despite these negative trends there is surprisingly strong support for EU-wide immigration and asylum policy.

Studies of opinion in the early 2000s suggested that support for immigration policy to be determined at the EU level, rather than at the national level, was substantial but not overwhelmingly strong. Luedtke (2005) noted that, in 2000, 43 percent of Eurobarometer respondents supported a joint EU policy. He found that individuals who identified only with their own country (rather than expressing a European or a joint identity), were strongly against EU-wide immigration policy. He speculated that this effect might weaken over time. Analysing a similar question in the ESS 2002, I found that support for joint policy on immigration and asylum was positively associated with trust in both the national and the European parliaments (Hatton 2015a).

However, these cross sectional analyses tell us little about how attitudes towards EU-level immigration policy have changed over time. Unfortunately the data is somewhat limited. Table 11 provides some evidence from Eurobarometer surveys at five year intervals since 2000 . These are answers to the question: "For each of the following areas, do you think that decisions should be made by the (national) government or made jointly within the European Union?" The first column refers to the percentage of respondents who, in 2000, thought that decisions on asylum policy should be made at the EU level. Among the EU-15 these were the majority in one third of the countries, but with a wide range from around a quarter in Austria and Britain to over 70 percent in Italy and the Netherlands. The next column shows the responses in the same wave for immigration policy (the same data that was analysed by Luedtke, 2005), rather than asylum policy. The overall means are very similar and the correlation across countries is 0.98 . Unfortunately subsequent surveys refer only to immigration policy and not specifically to asylum. Nevertheless, it appears that residents of any given country take a very similar view on the preferred decision-level for both immigration and asylum.

The responses on immigration policy that appear in subsequent rounds of Eurobarometer (columns 3 and 4), suggest a substantial increase in support for EU-level decision-making and, by inference, for joint EU policy on asylum. Focusing on the EU-15, the country mean increased by 16 percentage points over the decade from 2000 and the number of countries for which a majority preferred EU-level policy increased from one third to two thirds. Supporters also form a majority in every one of the countries that joined the EU in the accessions of 2004 and 2008. Unfortunately, Eurobarometer subsequently stopped asking the identical question and substituted another question instead. This is even more direct: "Please tell me whether you are for it or against it....A common European policy on migration." The percentage in favour is higher still than it was in the responses to the previous question in 2010. In part, that may be because respondents were not explicitly offered the alternative of national-level policy. 
Nevertheless, in response to this question there is majority support for EU level policy in every single country. ${ }^{20}$

So why the dramatic increase in support for EU-level policy against a background of rising Euroscepticism? One possibility is that respondents may have interpreted the question to imply that their country would have fewer immigrants if policy was set at the EU level. Evidence from Transatlantic Trends indicates that the individual-level correlation between preference for EU policy-making and holding the opinion that there are 'too many' immigrants or that immigration is 'more of a problem than an opportunity' is marginally negative. Neither is there a positive correlation between a preference for EU policy making and the opinion that the national government has done a poor or very poor job in managing immigration. It seems more likely that public opinion has recognised that at least some elements of policy would be more effective if managed at the EU level.

Nowhere is this more striking than in opinion on taking measures against illegal immigration. In 2015, Eurobarometer asked the question: "In your opinion, should additional measures be taken to fight illegal immigration from outside the EU?" If so, respondents were asked to state at what level such measures should be taken. As noted above, the overwhelming majority of respondents favour additional measures. Not surprisingly, as Table 12 shows, the percentages are very high in countries like Cyprus, Greece and Malta but the proportion supporting additional measures against illegal immigration is more than three quarters in every country except Romania. As illustrated in Table 12, opinion is divided between measures to be taken by the national government, the EU or both. Perhaps this is not surprising as some measures (such as employer sanctions) are inherently national while others are not. ${ }^{21}$ What stands out is the strong support for measures to be taken at the EU level alone or at both the EU and national levels. In every single country more than half of respondents favour tougher policies either at the EU level alone or in conjunction with the national government.

\section{Recent events and the future of asylum policy}

Future policy should be considered in the light of the forgoing analysis and in the context of recent history. To be realistic, policy must be developed in light of the trends in asylum applications and the forces driving them. But equally important for policy-making is its political feasibility. In a democratic setting, policy recommendations that fly in the face of public opinion will gain little traction. It is far better to work with the grain of public opinion than against it. This suggests three important areas for the development of policy.

- Border controls need to be tightened and enforced. This would limit the policy backlash arising from public concerns about unauthorised entry together with increased salience

\footnotetext{
${ }^{20}$ It is worth noting that the country-average percentage in favour of a common immigration policy is about the same as the proportion favouring a common energy policy and higher than the proportion in favour of a common foreign policy.

${ }^{21}$ In 2009 Transatlantic Trends asked four separate questions about what policies should be adopted at the national level to combat illegal immigration. The six-country averages of those that strongly agreed or somewhat agreed are: development aid: $67.0 \%$; border controls: $76.0 \%$; employer sanctions: $83.5 \%$; provide legal entry channels: $65.5 \%$
} 
of immigration as a policy issue. The fact that more than half of asylum applicants fail to qualify suggests that existing policy fails to select those most in need of humanitarian protection. But enhanced border controls will also restrict access for genuine refugees.

- Asylum policies must be refocused away from spontaneous asylum seeking towards a comprehensive resettlement programme that targets those in countries of first asylum with the most urgent protection needs. Greater support is also needed for those that remain in the camps and shanty towns.

- Capacity to host resettled refugees must be expanded through enhanced cooperation between European countries. This would require agreement on a distribution of resettlement quotas that is more even across countries than is produced by the existing system.

\section{Border controls}

Recent experience suggests that efforts to control the EU's external border have failed miserably. It would be easy to conclude, as many do, that such policies are inevitably doomed to failure: the more that barriers are erected, the more that desperate migrants will find ways around them. Studies of unauthorised border crossings from Mexico to the United States find that stronger enforcement at one crossing point displaces migrants to another crossing point (with the agency of smugglers) with modest effects on the overall flow (Hanson, 2006, Gathmann, 2008; Angelucci, 2012; Roberts et al. 2013; Massey et al. 2016). The recent European experience seems to demonstrate that perfectly. Yet the results from the regression analysis in Table 6 indicate that policies on access to the territory do have some effect, at least at the individual country level. This is also illustrated by the example of Australia (Box 1) where on two separate occasions, with an intervening policy relaxation, irregular maritime arrivals were reduced almost to zero.

Recent events also provide evidence to suggest that EU border control could be much more effective in stemming the flow of unauthorised migrants. As in the Mexico/US example, policy has been to effectively blockade some routes leaving others open (in the EU case even providing positive encouragement). Until 2012 the numbers coming across the Mediterranean, mainly from North Africa were modest. One reason is that EU governments struck agreements with origin and transit countries that involved in-country measures and interdictions at sea in order to stem the flow. In one case, Spain (aided by Frontex) reached agreements with countries of North and West Africa; in another Italy reached an agreement with Libya. ${ }^{22}$ These measures were effective in reducing unauthorised migration but the political void left by the Arab Spring reopened routes across the western and central Mediterranean. ${ }^{23}$ Table 13 shows the rising

\footnotetext{
22 Pérez (2010) describes the mix of visa policy, inter-governmental agreements, maritime patrols, electronic surveillance and reinforced perimeters around the enclaves of Ceuta and Melilla that successfully reduced illegal migration to Spain. On readmission agreements between Italy and North African countries, see Cuttitto (2010) who describes the mix of police cooperation, legal entry quotas and development and technical assistance that accompanied these agreements. Aziz et al (2015, p. 38) note that the Italian-led agreement with Libya, which led to a dramatic fall in maritime crossings in 2009 continued after the fall of Gaddafi but collapsed in 2012-13.

${ }^{23}$ Aziz et al (2015) examine the process of people smuggling (and trafficking) on the different routes through which migrants have managed to get to the external border of the EU. Humphris (2013) describes in detail the stages involved in the smuggling of Eritreans through Sudan and Egypt.
} 
number of unauthorised border crossings as estimated by Frontex. The total increased from a little over 150,000 in 2008 to more than 1.8 million in 2015. Notable also is the shifting patterns of migration from the West to East, culminating in an enormous movement though the Western Balkan and Eastern Mediterranean routes that by 2015 accounted for 90 percent of all unauthorised border crossings into the EU.

These developments were clearly influenced by policy, which has switched between restrictive and permissive on different routes. As the number of crossings mounted (notably to Lampedusa) Italy launched operation Mare Nostrum in October 2013, with the objective of rescuing those at risk of drowning. The policy was abandoned a year later as the numbers mounted and it was replaced by the Frontex-led operation Triton, which focused less on search and rescue and more on border protection. ${ }^{24}$ The routes taken have changed over time as a result both of changing conditions in transit countries and of EU border protection measures. Libya became a major transit route for migrants from the Middle East and Sub-Saharan Africa after the fall of the Gadaffi regime. ${ }^{25}$ But as Libya descended into anarchy and policing of the Western Mediterranean intensified, the major route across the Mediterranean shifted eastward, with Egypt as the hub. ${ }^{26}$ With the increasing pressure of migrants from Syria, the route through Turkey and across the Aegean rose to prominence (not only for Syrians), as migrants exploited the weakness of border controls through the Balkans.

Pressures increased as the war in Syria intensified and with the declaration of the ISIS Islamic Caliphate committed to war against the West. From that time displacements to Turkey, Lebanon and Jordan surged and mass movement through Turkey to Greece and on to other EU countries increased. These pressures met with border closures and restrictions, initially on the land border between Greece and Turkey, and later on the borders between Hungary and Serbia and between Bulgaria and Turkey. In August 2015, the German Chancellor, Angela Merkel, announced that Germany would welcome asylum seekers from Syria, Iraq and Afghanistan, which spurred further increases arrivals. Frontex recorded an increase in unauthorised border crossings on the western Balkan route from 35,559 in the second quarter of 2015 to 229,746 in the third quarter. Under the pressure of mounting numbers of migrants with strong preferences for destinations in the EU interior, the operation of the Dublin system was suspended in Mediterranean countries, and Mrs Merkel's welcome announcement brought about its complete collapse. Thus Greece and other members states on the EU's southern and eastern border became transit countries, often failing even to register the migrants passing through. A further consequence is that border controls were re-introduced in Schengen countries further north, including Denmark, Sweden and Belgium. As the system unravelled border controls

\footnotetext{
${ }^{24}$ This approach was inspired by Operation Atalanta, which from 2008 deployed ships of the EU Naval Force to patrol the Indian Ocean and the coast of Somalia in order to combat piracy, especially against vessels of the UN's World Food Programme. This was considered to have been fairly successful, as the success rate of pirate attacks fell, even though the total number did not (Bruns 2011).

${ }^{25}$ The process of smuggling of Eritreans through Sudan and Egypt is described in detail by Humprhris (2013).

26 The Italian-led agreement with Libya, which led to a dramatic fall in maritime crossings in 2009 continued after the fall of Gaddafi but collapsed in 2012-13 (Aziz et al. 2015, p. 38).
} 
shifted inward, and March 2016, six out of 22 members of the Schengen area had re-established controls on at least one of their borders.

The EU belatedly reached the conclusion that the only way to stem the flow of migrants is to eliminate, or at least reduce, the incentive to migrate. On 18th March 2016 it brokered an agreement with Turkey in exchange for financial aid for refugees located there and for reactivating the process of accession to the EU. The Turkish government agreed to take back migrants, in return for which the same number of refugees would be resettled in the EU direct from the camps. The number of migrants crossing on the Western Balkan route declined in the first quarter of 2016 as the barriers to onward movement from Greece became more binding. Following the EU-Turkey agreement the numbers decreased further and by July 2016 they were just 3 percent of the number in July 2015. While there may have been some substitution into alternative routes these effects seem to have been small; the numbers crossing on the Central Mediterranean route was about the same in the first half of 2016 as in the first half of 2015.

Recent history indicates that tough policies can be effective in reducing unauthorised entry, especially on maritime routes and especially in cooperation with transit countries. The shifts between different routes partly reflects changes in the origins of migrants and partly the weakness of Frontex, the role of which has been to advise and coordinate with national agencies rather than to provide an independent EU-wide border control system. ${ }^{27}$ But it also reflects a series of policy reversals and, in 2015, a complete abrogation of controls over the EU's south eastern external border. Tougher border controls are feasible on a practical level, and on a political level they are an important means of regaining public support for the asylum system. As we have seen, public opinion is strongly in favour of strengthening border controls and it is very negative about illegal immigration, and so reducing unauthorised entry is a priority. Even so, pressure on the EU's external border is likely to remain for the foreseeable future. But to the extent that policy succeeds in denying access to European territory, it will affect both 'economic migrants' and genuine refugees. This suggests the need for complementary measures to assist refugees.

\section{Refugee Support and Resettlement}

If we are serious in wanting to protect genuine refugees then this should be the focus of humanitarian effort. ${ }^{28}$ That effort should take two forms. The first is to devote resources to ameliorating conditions for those stuck in camps close to their origin country, many of whom are women and children, facing extreme hardship, disease, insecurity and often violence. The second is to embark on a massive resettlement scheme that would concentrate on recognised refugees whose applications have been processed in a country of first asylum and then transfer

\footnotetext{
${ }^{27}$ Haake et al. (2010) argue that border control can be interpreted as a locally provided public good. Even after the establishment of Frontex, border protection is still provided mainly by member states on the EU's external border while those inside the border tend to free-ride. Fink (2012) provides an account of the legal and operational weakness of Frontex.

${ }^{28}$ Not surprisingly many of those who are waiting for resettlement feel resentment against those that have chosen to migrate illegally (Koser and Kuschminder 2016).
} 
them directly to Europe. This would target those who are most in need protection rather than those that have sufficient resources and are willing to risk their lives in hazardous clandestine crossings by land or by sea. In contrast to the present system of spontaneous asylum seeking it would ensure that these arrivals do qualify as genuine refugees.

Not surprisingly, the recent focus has been on the displaced people located in Turkey. While the initial conditions in camps such as Kilis and Kahramanmaraş were exemplary, as compared with those in many countries of first asylum, the numbers have far outstripped capacity of the existing 22 camps (about 220,000). Resources are badly needed, in order to provide food and medicines as well as infrastructure for living accommodation and social services, particularly education. Further details are provided in Box 2. In Lebanon, where refugees make up a quarter of the population, conditions are worse. Many Syrians subsist in shanty towns such as Sabra and Shatila, on the outskirts of Beirut, where damp, overcrowded shelters and open sewers are serious health threats. ${ }^{29}$ And although refugees in the Middle East have received most of the recent attention, we should not overlook protracted refugee situations in the rest of the world where conditions are often worse. One example is the Dadaab camp in Northern Kenya, which is the largest in the world with a total of 330,000 inhabitants (mainly Somalis) in 2015, where there are serious threats to safety, where basic subsistence needs are barely met, ${ }^{30}$ and which has been threatened with closure in the aftermath of the massacre at Garissa University College. While the recent grant of a total of $€ 6$ billion to support refugees in Turkey is helpful, resources are badly needed in other locations too.

The UNHCR identifies three forms of durable solution for refugees, return to the country of origin, local integration in the country of first asylum, and resettlement in a third country. Over the years there have been a number of major initiatives that have incorporated these elements. Apart from the immediate postwar period, the two most successful programmes have been the International Conference on Central American Refugees (CIREFCA, 1987-94) and the Comprehensive Plan of Action for Indochinese Refugees (CPA, 1988-96). Both of these involved multilateral agreements that included origin countries, countries of first asylum and resettlement countries. The former focused on return and local integration of around 2 million displaced people from El Salvador, Guatemala and Nicaragua. ${ }^{31}$ The latter focused on return and particularly on the resettlement of more than half a million Vietnamese and Laotians. Several lessons can be learned from these programmes (Betts, 2006). One is that they were not simply one-off agreements but involved ongoing cooperative processes. Another is that they required resources from the western world and most importantly, leadership, either to bring the geopolitical interests of different countries into closer alignment or to help overcome the collective action problem.

\footnotetext{
29 These camps, which were formerly reserved for Palestinians were the scene of a notorious massacre in 1982 that claimed more than 2000 lives.

${ }^{30}$ For a graphic description of conditions in Dadaab, see Rawlence (2016).

31 The UNHCR's evaluation of the CIREFCA programme can be found at: http://www.unhcr.org/cgibin $/$ texis/vtx/search?page $=$ search \&docid $=3$ bd410804\&query $=$ Review $\% 20$ of $\% 20$ the $\% 20$ CIREFCA $\% 20$ Process.
} 
Apart from these specific programmes there has been an annual stream of resettlements facilitated mainly though the UNHCR. Under this system, displaced people in countries of first asylum are registered and their claim to refugee status is determined. Those for whom no other durable solution is feasible are designated on a case-by-case basis as in need of resettlement. And those that are considered to be most vulnerable or in the greatest need are then submitted to be considered by the countries that have committed to a programme of resettlement for a specific number of refugees. ${ }^{32}$ Despite a series of joint consultations and resolutions, the number of refugees resettled in developed countries has been pitifully small. ${ }^{33}$ The total number resettled fell from 150,000 in the early 1990 s to around 90,000 per annum in the last five years. ${ }^{34}$ The reasons for the failure to expand the number of resettlement places include the concerns of resettlement countries over the process of refugee selection in the wake of the 2001 attacks (Piper et al. 2013). More than half of the 73,331 resettlements facilitated by the UNHCR in 2014 went to the United States alone with 18 European countries taking just under 10,000 in total, more than a third of which went to Germany. Although the number of receiving countries grew from 14 in 2005 to 28 in 2015, most have very small quotas. By contrast, at the end of 2014, the UNHCR had assessed 1.15 million refugees that were in need of resettlement (UNHCR 2015c, p. 12).

In 2012 the EU agreed on a joint resettlement programme targeted at refugees selected for resettlement by the UNHCR, focusing on those located in countries or regions where common action would have a "significant impact in addressing protection needs" (EU Parliament and Council, 2012). Member states were invited to participate in the resettlement scheme on a voluntary basis with encouragement provided by financial support from European Refugee Fund of $€ 4,000$ per refugee resettled. ${ }^{35}$ Despite this inducement the results so far have been extremely modest. A likely reason is that countries facing a fluctuating and potentially large number of spontaneous asylum applications are reluctant to commit to substantial numbers for resettlement. Nevertheless, the fact that 18 European countries have embarked on some resettlement, most of them comparatively recently, indicates that this process is seen as a worthwhile element of the humanitarian programme. In response to the Syrian crisis European countries pledged 72,500 resettlement places. Although few have been resettled so far, this represents a considerable advance on what had gone before and could be built upon in the future. But a necessary precondition would be to implement border controls that reduce unauthorised entry and bring spontaneous asylum applications down to a manageable level.

\footnotetext{
${ }^{32}$ Those selected fulfil one of the following criteria: A legal or physical need for protection in the current situation; survivors of torture and/or violence; those with medical needs (e.g. for life saving treatment); women and girls at risk; family reunification; children and adolescents at risk; lack of alternative durable solutions. In 2014 over fourfifths of submissions were made under three submission categories: legal and/or physical protection needs (33\%), lack of foreseeable alternative durable solutions (26\%), and survivors of violence and/or torture (22\%) (UNHCR 2015a, p. 27).

33 These include the UNHCR's initiatives 'Agenda for Protection' in 2001 and 'Convention Plus' in 2004.

34 The number resettled with the assistance of the UNHCR averaged 69,711 per annum in 2010-14 (UNHCR, 2015c, p. 53).

${ }^{35}$ In April 2014, the European Refugee Fund was merged with the European Integration Fund and the European Return Fund, to form the Asylum, Migration and Integration Fund, with a budget of $€ 3.1$ billion for the period 2014-20.
} 


\section{Refugee-hosting capacity and burden-sharing}

A substantial resettlement programme would require radical expansion of refugee-hosting capacity through cooperation on burden-sharing between European states. It is worth elaborating briefly on the rationale for burden-sharing among refugee-receiving countries. A number of writers have argued that, for one reason or another, hosting refugees may be considered as having the characteristics of a public good (Suhrke 1998; Betts 2003; Roper and Barria 2010). That implies that such policies should be led by a supra-national body, such as the EU. But it is far from clear on these accounts precisely what the mechanism is and therefore what are the policy implications.

In order to provide such a motivation, it is useful draw a comparison with immigration policy. Immigration policies are often viewed from the perspective of whether they serve the interests of the host-country population, either specific individuals such as the sponsors of those coming though family reunification, or the wider economy, as in the case of skill-selective labour migration. By contrast, refugees are admitted on the grounds of the benefit them rather for any direct benefit to the host society or certain members of it. Indeed, the sole criterion of having a 'well-founded fear of persecution' is specific to the individual refugee and does not depend on his or her 'value' to the host country. Rather, the rationale for the host society of providing a safe haven for refugees is to satisfy basic humanitarian motives. It follows that the benefit to one host-country individual does not reduce the benefit to others, who cannot be effectively excluded. Thus, because this humanitarian benefit is non-rival and non-excludable, hosting refugees can be viewed as a public good.

If one country provides sanctuary for those fleeing persecution, then residents of another country benefit from the knowledge that these refugees have found safety. But the economic and social costs fall only on the country providing refuge. If each country sets its asylum policy independently, that policy will fail to take account of the benefits flowing to the residents of other countries. In such a case, the public good will be under-provided. A benevolent social planner would set policies that take the externality into account. Box 3 provides some simple analytics for the case of two destination countries that are each facing a flow of spontaneous asylum applications. Each country uses its policies (such as the policies on access and processing examined in section 4 above) to determine the number of applications. In this example, the optimum asylum policies are less restrictive than in the non-cooperative case but they still differ between countries that face different pressures of asylum applications. If policies were harmonised between the two countries then that would lead to divergence in refugee caseloads and such policies would need to be supplemented with some form of redistribution in order to reach the optimum.

Under the existing system of spontaneous asylum seeking individual countries set their policies without taking into account the externalities. As noted above the EU's Common European Asylum System that has been evolving since 1999 has focused mainly on harmonising policies and procedures for the reception, processing and integration of spontaneous asylum applicants. Although these policies are still far from uniform across member states there has been some convergence. And there is evidence that during the period 2001-6 when policy was tightened 
(Figure 4) this led to divergence in asylum applications (Hatton 2015, p. 617). Schemes for establishing a distribution key for the dispersal of asylum seekers across EU countries have often been proposed but have gained little traction - until very recently.

In August 2015, led by Germany, an 'agreement' was reached to redistribute a total of 160,000 refugees from Italy and Greece to other EU countries. This met with considerable resistance from a number of member states, notably those in Eastern Europe. The Hungarian Prime Minister Victor Orban commented on state radio that: "This is not solidarity. It is an unfair, unrighteous and dishonourable proposal which we cannot accept.... It is a crazy idea for someone to let refugees into their own country, not defend their borders, and then say: 'Now I will distribute them among you, who did not want to let anyone in."'(Associated Press 5/8/15). It is notable, however, that this comment refers to those that were allowed in by border control failures in other countries. Even more important, in 2015 Hungary received 174,000 asylum applications - more than four times the total of the previous year and 13 times the average for 2010-14. In this light the Hungarian reaction is not so surprising.

Clearly there is likely to be resistance to any policy of distributing refugees more evenly among European countries. This is in the very nature of public goods and it therefore requires the EU to act as the social planner. But it is worth repeating that there is considerable public support for immigration and asylum policies to be determined at the EU level. Also, it is important to draw a distinction between redistributing asylum seekers that are already present in EU countries and resettling refugees direct from countries of first asylum. It is at least possible that governments would take a more positive view of a resettlement programme for refugees in which they were stakeholders. One way to ease that process would be to introduce a market for tradeable refugee quotas that implicitly takes account of the political and economic costs faced by different governments. This could be combined with a matching mechanism to take account of the preferences of refugees for host countries and of host countries for different types of refugees (Fernández-Huertas Moraga and Rapoport 2015a, b). But it seems unlikely that agreement on large-scale ongoing resettlement programme could be reached while the number of spontaneous asylum applications is running at the rate of more than a million a year.

\section{Conclusion}

An asylum policy where eligibility for recognition as a refugee is conditional on a first stage in which the individual must risk his or her life and safety in a hazardous sea voyage on a leaky boat, at the mercy of people smugglers, often followed by a long trek in the cold and wet dodging fences and border guards, seems like a very unsatisfactory policy. One that also selects for the trip many that do not ultimately qualify for refugee status once they have arrived at their selected destination, who are often impossible to repatriate and end up in the limbo of the informal sector, seems to be very badly targeted. And one that leaves behind many of those that are in the greatest need of protection and does little to assist them in the camps and the shanty towns where they are abandoned makes it seem even worse. In fact, it is utterly crazy.

In the last three years an epic spectacle has unfolded that has raised public alarm to an unprecedented level. Week by week the media has documented the travails of migrants and 
plight of refugees as the Syrian tragedy has evolved. The response of the EU and individual governments has been slow and widely criticised. As we have seen, tougher border controls can be effective in staunching the flow of migrants, particularly maritime arrivals, and the EU has moved inexorably towards an Australian-style approach of reducing the incentive to migrate by boat. This is not surprising in the light of the widespread concerns about illegal immigration. The package agreed between the EU and Turkey in March 2016 has helped to stem the flow of migrants by reducing the incentive to migrate while resettling one refugee for each migrant sent back to Turkey. One recent development is to transform Frontex is into a new European Border and Coastguard Agency, with much wider powers to intervene and to directly implement border protection policy.

Thus the crisis has galvanised the EU into taking some steps to move away from a regime of spontaneous migration in search of asylum and towards a regime in which refugees are taken into Europe through resettlement. According to the statement issued by the EU Commission and Council in April 2016:

The overall objective is to move from a system which by design or poor implementation places a disproportionate responsibility on certain Member States and encourages uncontrolled and irregular migratory flows to a fairer system which provides orderly and safe pathways to the EU for third country nationals in need of protection or who can contribute to the EU's economic development. The EU needs a robust and effective system for sustainable migration management for the future that is fair for host societies and EU citizens as well as for third country nationals and countries of origin and transit. For it to work, this system must be comprehensive, and grounded on the principles of responsibility and solidarity (EU Commission and Council, 2016, p. 2)

This agenda concentrates on scenarios for revamping the Dublin regulation with the possibility of using a distribution key, on further harmonisation, on border control and limiting secondary movements, and on strengthening the mandate of the European Asylum Support Office. Although there is a commitment to resettlement in order to "ensure that the EU takes its fair share of global responsibility" (p. 15), the details have yet to be elaborated. While recent events have put resettlement clearly on the agenda, the magnitude of the crisis has created an impediment to generating the resettlement places that are so badly needed. But shifting to resettlement should be the long run goal. A substantial resettlement programme could also, over time, substantially reduce the incentive for spontaneous migration, with all the risks and traumas that that involves. And while formal burden sharing schemes are now being taken more seriously, their potential to increase the total capacity to host refugees has not been realised. If applied to a resettlement programme this could command much more widespread public support. Indeed, an important argument for shifting to such an alternative refugee regime is that it would work with the grain of public opinion rather than against it, as the current system evidently does. 


\section{References}

Adhikari, P. (2012), "The Plight of the Forgotten Ones: Civil War and Forced Migration," International Studies Quarterly, 56, pp. 590-606.

Alvarado, S. E. and Massey, D. S. (2010), "In Search of Peace: Structural Adjustment, Violence, and International Migration, "Annals of the American Academy of Political and Social Science, 630, pp. 137-161.

Angelucci. M. (2012), "US Border Enforcement and the net Flow of Mexican Illegal Migration," Economic Development and Cultural Change, 60, pp. 311-317.

Armigeon, K. and Ceka, B. (2014), "The Loss of Trust in the European Union during the Great Recession since 2007: The Role of Heuristics from the National Political System," European Union Politics, 15, pp. 82-107.

Aziz, N. A., Monzini, P. and Pastore, F. (2015), Changing Dynamics of Cross-border Human Smuggling and Trafficking in the Mediterranean, Rome: Instituto Affari Internazionale.

Barthel, F. and Neumayer, E. (2015), "Spatial Dependence in Asylum Migration," Journal of Ethnic and Migration Studies, 41, pp. 1131-1151.

Bertoli, S, and Fernández-Huertas Moraga, J. (2013), "Multilateral Resistance to Migration," Journal of Development Economics, 102, pp. 79-100

Besley, T. and Reynal-Querol, M. (2014), "The Legacy of Historical Conflict: Evidence from Africa," American Political Science Review, 108, pp. 319-336.

Betts, A. (2003), "Public Goods Theory and the Provision of Refugee Protection: The Role of the Joint-Product Model in Burden-Sharing Theory," Journal of Refugee Studies, 16, pp. 274296.

Betts, A. (2006), "Comprehensive Plans of Action: Insights from CIREFCA and the Indochinese CPA,” UNHCR, New Issues in Refugee Research, Paper No 120.

Bruns, S. (2011), “Operation ATALANTA at Three: A Success or Failure?" Strategic Insights, 36, pp. 8-12.

Cassarino, J-P. (2010). "Readmission Policy in the European Union" Brussels: Committee on Civil Liberties, Justice and Home Affairs, European Parliament.

Cassarino, J-P. (2014), “A Reappraisal of the EU's Expanding Readmission System,” International Spectator, 49, pp. 130-145.

Ceobanu, A. M. and Escandell, X. (2010), "Comparative Analyses of Public Attitudes Toward Immigrants and Immigration Using Multinational Survey Data: A Review of Theories and Research," Annual Review of Sociology, 36, pp. 309-28. 
Cuttitto, P. (2010), "Readmission in the Relations between Italy and North African Mediterranean Countries," in J-P. Cassarino (ed.), Unbalanced Reciprocities: Cooperation on Readmission in the Euro-Mediterranean Area, Florence: European University Institute.

Czaika, M. and de Haas, H. (2013), “The Effectiveness of Immigration Policies," Population and Development Review, 39, pp. 487-508.

Davenport, C. A., Moore, W. H. and Poe, S. C. (2003), "Sometimes You Just Have to Leave: Domestic Threats and Forced Migration, 1964-1989," International Interactions, 29, pp. $27-$ 55.

Del Carpio, X. V. and Wagner, M. (2015), "The Impact of Syrian Refugees on the Turkish Labor Market,” World Bank Policy Research, Working Paper 7402.

Docquier, F. and Marfouk, A. (2006), 'International Migration by Educational Attainment (1990-2000)," in C. Ozden and M. Schiff (eds), International Migration, Remittances and the Brain Drain, London: Palgrave-Macmillan.

Engel, S, and Ibáñez, A. M. (2007), "Displacement due to Violence in Colombia: A Household-Level Analysis," Economic Development and Cultural Change, 55, pp. 335-365.

Erdoğan, M. (2014), "Syrians in Turkey: Social Acceptance and Integration Research," Migration and Politics Research Centre, Haceteppe University.

European Commission and Council (2016), "Towards a Reform of the Common European Asylum System and Enhancing Legal Avenues to Europe," at: http://ec.europa.eu/dgs/homeaffairs/what-we-do/policies/european-agenda-migration/proposal-implementationpackage/docs/20160406/towards_a_reform_of_the_common_european_asylum_system_and_ enhancing_legal_avenues_to_europe__20160406_en.pdf.

European Union Parliament and Council (2012), Decision No 281/2012/EU at: http://eurlex.europa.eu/LexUriServ/LexUriServ.do?uri=OJ:L:2012:092:0001:0003:EN:PDF.

Eurostat (2015), “Asylum Applicants and First Instance Decisions on Asylum Applications: 2014,” at: http://ec.europa.eu/eurostat/en/web/products-data-in-focus/-/KS-QA-15-003.

Facchini, G., Mayda A. M. and Puglisi, R. (2011), "Illegal Immigration and Media Exposure: Evidence on Individual Attitudes," University of Nottingham, unpublished paper.

Fearon, J. D. and Laitin, D. D. (2013), “How Persistent is Armed Conflict?” unpublished paper at: https://esoc.princeton.edu/files/how-persistent-armed-conflict.

Fernández-Huertas Moraga, J., and Rapoport, H. (2015), “Tradable Refugee-admission Quotas and EU Asylum Policy,” CESifo Economic Studies, 61, pp. 638-672. 
Fernández-Huertas Moraga, J., and Rapoport.H. (2015b), “Tradable Refugee-admission Quotas (TRAQs), the Syrian Crisis and the New European Agenda on Migration," IZA Journal of European Labor Studies, 4.

Fink, M. (2012), "Frontex Working Arrangements: Legitimacy and Human Rights Concerns Regarding 'Technical Relationships'," Merkourios, 28, pp. 20-35.

Ford, R., Jennings, W. and Somerville, W. (2015), "Public Opinion, Responsiveness and Constraint: Britain's Three Immigration Policy Regimes," Journal of Ethnic and Migration Studies, (online first).

Freeman, G. (1994), "Britain, the Deviant Case," in W. Cornelius, P. L. Martin and J. F. Hollifield, Controlling Immigration: A Global Perspective, Palo Alto: Stanford University Press.

Frontex (2010), "Unaccompanied Minors in the Migration Process," at: http://frontex.europa.eu/assets/Attachments_News/unaccompanied_minors_public_5_dec.pdf

Gathmann, C. (2008), "Effects of Enforcement on Illegal Markets: Evidence from Migrant Smuggling along the Southwestern Border," Journal of Public Economics, 98, pp. 19261941.

Haake, C-J., Krieger, T. and Minter, S. (2010), "External Border Enforcement, Public Goods and Burden Sharing Mechanisms in the EU," in R. Zapata-Barrero (ed), Shaping the Normative Contours of the European Union: A Migration-Border Framework, Barcelona UPF Centre for International Affairs.

Hailbronner, K. (1994), “Asylum Law Reform in the German Constitution,” American University International Law Review, 9, pp. 159-179.

Hainmueller, J. and Hopkins, D. (2014), "Public Attitudes toward Immigration," Annual Review of Political Science, 17, pp. 11.1-11.25.

Hanson, G. H. (2006), "Illegal Migration from Mexico to the United States," Journal of Economic Literature, 44, pp. 869-924.

Hatton, T. J. (2004), “Seeking Asylum in Europe”, Economic Policy, 38, 5-62.

Hatton, T. J. (2009), "The Rise and Fall of Asylum: What Happened and Why?" Economic Journal, 119, pp. F183-F213.

Hatton, T. J. (2015a), "Asylum Policy in the EU: The Case for Deeper Integration," CESifo Economic Studies, 61, pp. 605-637.

Hatton, T. J. (2015b), "Public Opinion on Immigration in Europe: Preference versus Salience," Unpublished paper. 
Hatton, T. J. (2016), "Immigration, Public Opinion and the Recession in Europe," Economic Policy, 87, pp. 205-246.

Hatton, T. J. and Moloney, J. (2015), The Determinants of Applications for Asylum: Modelling Asylum Claims by Origin and Destination" London: CEPR Discussion Paper 10678.

Humphris, R. (2013), "Refugees and the Rashaida: Human Smuggling and Trafficking from Eritrea to Sudan and Egypt," UNHCR: New Issues in Refugee Research, Paper No. 254.

Karlsen, E., Phillips, J. and Koleth, E. (2011), “Seeking Asylum: Australia’s Humanitarian Program,” Australian Parliamentary Library, at: http://www.aph.gov.au/binaries/library/pubs/bn/sp/seekingasylum.pdf

Koser, K. and Kuschminder, K. (2016), “Understanding Irregular Migrants' Decision Making Factors in Transit," Australia Department of Immigration and Border Protection, Occasional Paper 21.

Luedtke, A. (2005), "European Integration, Public Opinion and Immigration Policy: Testing the Impact of National Identity," European Union Politics, 6, pp. 83-112.

Massey, D. S., Durand, J. and Pren, K. A. (2016), "Why Border Enforcement Backfired," American Journal of Sociology, 121, pp. 1-44.

Melander, E. and Öberg, M. (2006), "Time to Go? Duration Dependence in Forced Migration," International Interactions, 32, pp. 129-152.

Melander, E. and Öberg, M. (2007), "The Threat of Violence and Forced Migration: Geographical Scope Trumps Intensity of Fighting," Civil Wars, 9, pp. 156-173.

Moore, W. H. and Shellman, S. M. (2004), "Fear of Persecution: Forced Migration, 19521995," Journal of Conflict Resolution, 40, pp. 727-53.

Moore, W. H. and Shellman, S. M. (2006), "Refugee or Internally Displaced Person? To Where Should One Flee?” Comparative Political Studies 39, pp. 599-622.

Moore, W. H., and Shellman S. M. (2007), "Whither Will They Go? A Global Study of Refugees' Destinations, 1965-1995," International Studies Quarterly, 51, pp. 811-834.

Neumayer, E. (2004), "Asylum Destination Choice: What Makes some West European Countries More Attractive than Others?” European Union Politics, 5, pp. 155-80.

Neumayer, E. (2005), "Bogus Refugees? The Determinants of Asylum Migration to Western Europe," International Studies Quarterly, 49, pp. 389-409.

Pérez, A. (2010) “The Externalization of Migration Control in Spain and Its Impact on Moroccan and Ecuadorian Migration," in R. Zapata-Barrero (ed), Shaping the Normative 
Contours of the European Union: A Migration-Border Framework, Barcelona UPF Centre for International Affairs.

Phillips J. (2015), “Boat Arrivals and Boat 'Turnbacks' in Australia since 1976: A Quick Guide to the Statistics," Australian Parliamentary Library at:

http://apo.org.au/files/Resource/parliamentarylibrary_boatarrivalsandboatturnbacksinaustralia since1976_sep_2015.pdf

Piper, M., Power, P. and Thom, G. (2013), "Refugee Resettlement: 2012 and Beyond," UNHCR, New Issues in Refugee Research Paper 253.

Rawlence, B. (2016), City of Thorns: Nine Lives in the World's Largest Refugee Camp, London: Portobello Books.

Roberts, B., Alden, E. and Whitley, J. (2013), Managing Illegal Immigration to the United States: How Effective is Enforcement? Washington, DC: Council on Foreign Relations.

Roper, S. D. and Barria, L. A. (2010), "Burden Sharing in the UNHCR: Refugee Protection as an Impure Public Good," Journal of Conflict Resolution, 54, pp. 616-637.

Steele, A. (2009) "Seeking Safety: Avoiding Displacement and Choosing Destinations in Civil Wars," Journal of Peace Research, 46, pp. 419-429.

Suhrke A. (1998), "Responsibility-sharing during Refugee Emergencies: The Logic of Collective Action versus National Action," Journal of Refugee Studies, pp. 396-415.

Thielemann, Eiko (2006), "The Effectiveness of Governments' Attempts to Control Unwanted Migration," in C. A. Parsons and T. M. Smeeding (eds), Immigration and the Transformation of Europe, Cambridge: Cambridge University Press, pp. 442-472.

Thielemann, E. and El-Enany, N. (2009), "Beyond Fortress Europe? How European Cooperation Strengthens Refugee Protection," London School of Economics: unpublished paper.

Tumen, S. (2016), “The Economic Impact of Syrian Refugees on Host Countries: QuasiExperimental Evidence from Turkey," American Economic Review ( $P$ \& P) 106, pp. 456-60.

Schmeidl, S. (1997), "Exploring the Causes of Forced Migration: A Pooled Time Series Analysis," Social Science Quarterly, 78, pp. 284-308.

UK Home Office (2016), "Immigration Statistics" at: https://www.gov.uk/government/publications/immigration-statistics-january-to-march2016/asylum.

UNHCR (2001), Asylum Applications in Industrialized Countries, 1980-1999 Geneva: UNHCR. 
UNHCR (2015a), Global Trends: Forced Displacement in 2014, Geneva: UNHCR.

UNHCR (2015b), “Total Refugee Population by Country of Asylum, 1960-2013 \& Total Refugee Population by Origin, 1960-2013," at: http://www.unhcr.org/pages/4a013eb06.html.

UNHCR (2015c), Projected Global Resettlement Needs, 2016, Geneva: UNHCR.

UNHCR (2016), Global Trends: Forced Displacement in 2015, Geneva: UNHCR.

UNHCR (Various Issues), “Asylum Trends: Levels and Trends in Industrialized Countries,” Geneva: United Nations High Commissioner for Refugees.

Wlezien, C. (2005), "On the Salience of Political Issues: The Problem with 'Most Important Problem,," Electoral Studies, 24, pp. 555-579.

York, B. (2003), “Australia and Refugees, 1901-2002: An Annotated Chronology Based on Official Sources," Australian Parliamentary Library at:

http://www.aph.gov.au/binaries/library/pubs/online/03chr02.pdf. 
Table 1: Top 20 origin countries for asylum applications to the $\mathbf{E U}$

\begin{tabular}{|l|r|l|c|l|c|l|r|}
\hline \multicolumn{4}{|c|}{ Annual applications 2006 to 2010} & \multicolumn{4}{c|}{ Annual applications 2011 to 2015 } \\
\hline Iraq & 23,491 & Bangladesh & 5,713 & Syria & 129,356 & Iran & 15,074 \\
\hline Serbia & 16,670 & Sri Lanka & 5,439 & Afghanistan & 71,180 & Bangladesh & 11,479 \\
\hline Russia & 16,650 & Eritrea & 5,403 & Serbia & 52,298 & Macedonia & 8,388 \\
\hline Afghanistan & 13,748 & China & 5,251 & Iraq & 38,011 & Georgia & 8,363 \\
\hline Somalia & 13,169 & DR Congo & 4,494 & Pakistan & 28,714 & DR Congo & 7,904 \\
\hline Pakistan & 10,030 & Armenia & 4,335 & Russia & 22,958 & Ukraine & 7,848 \\
\hline Nigeria & 7,851 & Syria & 4,228 & Eritrea & 22,511 & Mali & 6,868 \\
\hline Iran & 7,337 & Zimbabwe & 3,834 & Albania & 21,892 & Sri Lanka & 6,424 \\
\hline Turkey & 6,244 & Guinea & 3,167 & Nigeria & 16,568 & Algeria & 6,221 \\
\hline Georgia & 5,722 & India & 3,117 & Somalia & 16,403 & Gambia & 6,148 \\
\hline
\end{tabular}

Sources: UNHCR, Asylum Levels and Trends in Industrialized Countries, Table 5 for 2006-14; UNHCR Global Trends, 2015, Table 12.

Notes: Serbia includes Kosovo; "stateless" accounts for 9,388 applications in 2006-10 and 51,518 in 2011-15.

Table 2: Annual Average Asylum Applications, by Country of Asylum

\begin{tabular}{|l|r|r|r|l|r|r|r|}
\hline & $2001-05$ & $2006-10$ & $2011-15$ & & $2001-05$ & $2006-10$ & $2011-15$ \\
\hline Austria & 29,788 & 12,988 & 30,720 & Latvia & 16 & 40 & 282 \\
\hline Belgium & 18,324 & 14,782 & 21,919 & Lithuania & 204 & 214 & 383 \\
\hline Bulgaria & 1,764 & 850 & 8,010 & Luxembourg & 1,132 & 526 & 1,669 \\
\hline Cyprus & 8,148 & 4,324 & 1,717 & Malta & 642 & 1,558 & 1,820 \\
\hline Czech R & 9,518 & 1,692 & 731 & Netherlands & 17,356 & 12,642 & 19,437 \\
\hline Denmark & 5,734 & 2,858 & 10,173 & Norway & 9,652 & 10,714 & 13,339 \\
\hline Estonia & 10 & 20 & 126 & Poland & 6,310 & 7,192 & 8,781 \\
\hline Finland & 3,148 & 3,542 & 7,465 & Portugal & 158 & 162 & 486 \\
\hline France & 56,262 & 37,146 & 60,154 & Romania & 1,182 & 798 & 1,709 \\
\hline Germany & 54,900 & 26,252 & 166,966 & Slovakia & 8,630 & 1,556 & 295 \\
\hline Greece & 6,572 & 16,692 & 9,585 & Slovenia & 1,238 & 324 & 287 \\
\hline Hungary & 4,314 & 3,088 & 47,629 & Spain & 6,284 & 4,646 & 5,952 \\
\hline Iceland & 84 & 50 & 175 & Sweden & 25,716 & 28,210 & 71,870 \\
\hline Ireland & 7,790 & 3,360 & 1,536 & Switzerland & 18,524 & 13,326 & 25,013 \\
\hline Italy & 11,674 & 16,474 & 44,851 & U. K. & 65,238 & 28,250 & 30,274 \\
\hline & & & & Total & 380,312 & 254,276 & 593,355 \\
\hline
\end{tabular}

Sources: UNHCR, Asylum Levels and Trends in Industrialized Countries (various years) Table 1; data for 2015 from UNHCR Global Trends 2015, Table 9. 
Table 3: Refugees in host countries

\begin{tabular}{|l|r|r|r|l|r|r|r|}
\hline Country & Refugees & $\begin{array}{l}\text { Refs/ } \\
\text { Pop }\end{array}$ & $\begin{array}{l}\text { Refs/ } \\
\text { GDP }\end{array}$ & Country & Refugees & $\begin{array}{l}\text { Refs/ } \\
\text { Pop }\end{array}$ & $\begin{array}{l}\text { Refs/ } \\
\text { GDP }\end{array}$ \\
\hline Germany & 316,115 & 3.92 & 0.10 & Turkey & $2,541,352$ & 32.79 & 3.70 \\
\hline USA & 273,202 & 0.86 & 0.02 & Pakistan & $1,561,162$ & 8.44 & 10.37 \\
\hline France & 273,126 & 4.26 & 0.12 & Lebanon & $1,070,854$ & 190.82 & 26.30 \\
\hline Sweden & 169,520 & 17.48 & 0.38 & Iran & 979,437 & 12.54 & 3.54 \\
\hline Canada & 135,888 & 3.82 & 0.10 & Ethiopia & 736,086 & 7.59 & 24.04 \\
\hline UK & 123,067 & 1.91 & 0.05 & Jordan & 664,118 & 89.56 & 31.11 \\
\hline Italy & 118,047 & 1.98 & 0.07 & Kenya & 553,912 & 12.35 & 18.74 \\
\hline Netherlands & 88,536 & 5.25 & 0.12 & Uganda & 477,187 & 12.63 & 28.99 \\
\hline Switzerland & 73,336 & 8.94 & 0.15 & D R Congo & 383,095 & 5.12 & 18.06 \\
\hline Austria & 72,216 & 8.48 & 0.21 & Chad & 369,540 & 27.20 & 35.49 \\
\hline Norway & 50,389 & 9.79 & 0.15 & Cameroon & 327,121 & 16.75 & 16.36 \\
\hline Australia & 36,917 & 1.57 & 0.04 & Russia & 314,506 & 2.19 & 0.32 \\
\hline Belgium & 35,314 & 3.15 & 0.08 & Sudan & 309,639 & 8.94 & 9.19 \\
\hline Denmark & 27,326 & 4.84 & 0.10 & China & 301,052 & 0.22 & 0.06 \\
\hline Greece & 18,489 & 2.38 & 0.13 & Iraq & 277,701 & 7.88 & 3.23 \\
\hline
\end{tabular}

Source: UNHCR, Global Trends, 2015, Table 1; Real GDP in \$US (2010) and population from the World Bank at: http://data.worldbank.org/indicator/NY.GDP.PCAP.KD.

Table 4: Components of the policy index

\begin{tabular}{|l|l|l|}
\hline Access policies & Processing polices & Welfare policies \\
\hline Visa requirements & Definition of a refugee & Permission to work \\
\hline Border control/security & Humanitarian category & Access to welfare benefits \\
\hline Trafficking regulations & Manifestly unfounded claims & Detention policy \\
\hline Carrier sanctions & Expedited procedures & Deportation policy \\
\hline Application outside country & Scope for appeals & Family reunification \\
\hline
\end{tabular}

Source: Author calculations, see data appendix. 
Table 5: Asylum Applications by Origin and Destination, 1997-2014

\begin{tabular}{|c|c|c|c|c|c|}
\hline & (1) & (2) & (3) & (4) & (5) \\
\hline Political terror scale & $\begin{array}{l}0.197 * * * \\
(3.72)\end{array}$ & $\begin{array}{l}0.231 * * * \\
(4.32)\end{array}$ & $\begin{array}{l}0.238 * * * \\
(4.32)\end{array}$ & $\begin{array}{l}0.221 * * * \\
(4.45)\end{array}$ & $\begin{array}{l}0.237 * * * \\
(3.91)\end{array}$ \\
\hline $\begin{array}{l}\text { Civil liberties } \\
\text { (Freedom House) }\end{array}$ & $\begin{array}{l}0.243^{* * * *} \\
(4.04)\end{array}$ & $\begin{array}{l}0.249^{* * * *} \\
(4.08)\end{array}$ & $\begin{array}{l}0.247 * * * \\
(3.94)\end{array}$ & $\begin{array}{l}0.255^{* * * *} \\
(4.33)\end{array}$ & $\begin{array}{l}0.289^{* * * *} \\
(3.91)\end{array}$ \\
\hline $\begin{array}{l}\text { Political rights } \\
\text { (Freedom House) }\end{array}$ & $\begin{array}{l}-0.028 \\
(0.57)\end{array}$ & $\begin{array}{l}-0.030 \\
(0.68)\end{array}$ & $\begin{array}{l}-0.028 \\
(0.62)\end{array}$ & $\begin{array}{l}-0.028 \\
(0.63)\end{array}$ & $\begin{array}{l}-0.022 \\
(0.39)\end{array}$ \\
\hline $\begin{array}{l}\text { Civil war battle } \\
\text { deaths/origin popn }\end{array}$ & $\begin{array}{l}0.180 \\
(0.95)\end{array}$ & $\begin{array}{r}0.196 \\
(0.99)\end{array}$ & $\begin{array}{r}0.173 \\
(0.81)\end{array}$ & $\begin{array}{l}-0.181 * \\
(1.99)\end{array}$ & $\begin{array}{l}0.163 \\
(0.77)\end{array}$ \\
\hline $\begin{array}{l}\text { Log origin country } \\
\text { real GDP per capita }\end{array}$ & $\begin{array}{l}-0.797 * * * \\
(3.26)\end{array}$ & $\begin{array}{l}-0.619 * * \\
(2.48)\end{array}$ & $\begin{array}{l}-0.605^{* *} \\
(2.32)\end{array}$ & $\begin{array}{l}-0.427 * \\
(1.92)\end{array}$ & $\begin{array}{l}-0.665^{* * *} \\
(2.34)\end{array}$ \\
\hline $\begin{array}{l}\text { Log migrant stock in } \\
2000-1 \text { /origin popn. }\end{array}$ & $\begin{array}{l}0.227 * * * \\
(8.69)\end{array}$ & $\begin{array}{l}0.227 * * * \\
(8.68)\end{array}$ & & & \\
\hline $\begin{array}{l}\text { Log distance from } \\
\text { source to destination }\end{array}$ & $\begin{array}{l}-0.826 * * * \\
(4.27)\end{array}$ & $\begin{array}{l}-0.827 * * * \\
(4.27)\end{array}$ & & & \\
\hline $\begin{array}{l}\text { Log destination } \\
\text { GDP per capita }\end{array}$ & $\begin{array}{l}-0.329 \\
(0.92)\end{array}$ & $\begin{array}{l}-0.036 \\
(0.07)\end{array}$ & $\begin{array}{l}-0.110 \\
(0.22)\end{array}$ & $\begin{array}{l}-0.251 \\
(0.52)\end{array}$ & $\begin{array}{l}-0.512 \\
(1.01)\end{array}$ \\
\hline $\begin{array}{l}\text { Unemployment rate } \\
\text { at destination }\end{array}$ & $\begin{array}{l}-0.043 * * * \\
(4.36)\end{array}$ & $\begin{array}{l}-0.030 * * * \\
(2.84)\end{array}$ & $\begin{array}{l}-0.032 * * * \\
(3.05)\end{array}$ & $\begin{array}{l}-0.032 * * * \\
(3.08)\end{array}$ & $\begin{array}{l}-0.042 * * * \\
(3.75)\end{array}$ \\
\hline Policy index & $\begin{array}{l}-0.059 * * * \\
(5.18)\end{array}$ & $\begin{array}{l}-0.065^{* * *} \\
(5.56)\end{array}$ & $\begin{array}{l}-0.058 * * * \\
(5.10)\end{array}$ & $\begin{array}{l}-0.057 * * * \\
(4.99)\end{array}$ & $\begin{array}{l}-0.054 * * * \\
(4.43)\end{array}$ \\
\hline Year & $\begin{array}{l}0.054 * * \\
(2.88)\end{array}$ & & & & \\
\hline Distance $\times$ Year & & & & $\begin{array}{l}-0.015 \\
(0.061)\end{array}$ & \\
\hline $\begin{array}{l}\text { Battle deaths/popn } \times \\
\text { Year }\end{array}$ & & & & $\begin{array}{l}0.061 * * * \\
(8.07)\end{array}$ & \\
\hline $\begin{array}{l}\text { Fixed effects } \\
\text { (number of FE) }\end{array}$ & $\begin{array}{l}\text { Origin } \\
(48)\end{array}$ & $\begin{array}{l}\text { Origin } \\
(48)\end{array}$ & $\begin{array}{l}\text { Orig } \times \text { Dest } \\
(626)\end{array}$ & $\begin{array}{l}\text { Orig } \times \text { Dest } \\
(626)\end{array}$ & $\begin{array}{l}\text { Orig } \times \text { Dest } \\
(503)\end{array}$ \\
\hline $\begin{array}{l}\text { Destination } \\
\text { dummies }\end{array}$ & Yes & Yes & No & No & No \\
\hline Year dummies & No & Yes & Yes & Yes & Yes \\
\hline $\mathrm{R}^{2}$ Within & 0.397 & 0.414 & 0.130 & 0.145 & 0.129 \\
\hline No of Obs. & 10875 & 10875 & 10875 & 10875 & 8760 \\
\hline
\end{tabular}

Note: ' $z$ ' statistics in parentheses from standard errors clustered by origin country; significance at 1, 5 and 10 percent denoted by $* * *, * *$ and $*$ respectively. Constant terms and coefficients on destination dummies and year dummies are not reported. 
Table 6: Asylum applications and policy, 1997-2014

\begin{tabular}{|c|c|c|c|c|c|}
\hline & $(1)$ & (2) & (3) & (4) & (5) \\
\hline $\begin{array}{l}\text { Log migrant stock in } \\
2000-1 / \text { origin popn. }\end{array}$ & $\begin{array}{l}0.227 * * * \\
(8.67)\end{array}$ & $\begin{array}{l}0.228 * * * \\
(8.68)\end{array}$ & $\begin{array}{l}0.228 * * * \\
(8.68)\end{array}$ & $\begin{array}{l}0.223 * * * \\
(8.33)\end{array}$ & $\begin{array}{l}0.223 * * * \\
(8.33)\end{array}$ \\
\hline $\begin{array}{l}\text { Log distance from } \\
\text { source to destination }\end{array}$ & $\begin{array}{l}-0.817 * * * \\
(4.21)\end{array}$ & $\begin{array}{l}-0.819 * * * \\
(4.21)\end{array}$ & $\begin{array}{l}-0.819 * * * \\
(4.21)\end{array}$ & $\begin{array}{l}-0.790 * * * \\
(4.23)\end{array}$ & $\begin{array}{l}-0.790 * * * \\
(4.23)\end{array}$ \\
\hline $\begin{array}{l}\text { Log destination } \\
\text { GDP per capita }\end{array}$ & $\begin{array}{l}-0.121 \\
(0.26)\end{array}$ & $\begin{array}{l}-0.310 \\
(0.68)\end{array}$ & $\begin{array}{l}-0.336 \\
(0.74)\end{array}$ & $\begin{array}{l}-0.354 \\
(0.79)\end{array}$ & $\begin{array}{l}-0.206 \\
(0.43)\end{array}$ \\
\hline $\begin{array}{l}\text { Unemployment rate } \\
\text { at destination }\end{array}$ & $\begin{array}{l}-0.034 * * * \\
(3.31)\end{array}$ & $\begin{array}{l}-0.032 * * * \\
(3.23)\end{array}$ & $\begin{array}{l}-0.031 * * * \\
(3.04)\end{array}$ & $\begin{array}{l}-0.031 * * * \\
(3.05)\end{array}$ & $\begin{array}{l}-0.032 * * * \\
(3.23)\end{array}$ \\
\hline Policy index overall & $\begin{array}{l}-0.064 * * * \\
(5.59) \\
\end{array}$ & & & & \\
\hline Policy on access & & $\begin{array}{l}-0.160 * * * \\
(4.98)\end{array}$ & $\begin{array}{l}-0.159 * * * \\
(4.93)\end{array}$ & $\begin{array}{l}-0.153 * * * \\
(4.81)\end{array}$ & $\begin{array}{l}-0.148 * * * \\
(4.68)\end{array}$ \\
\hline Policy on processing & & $\begin{array}{l}-0.115^{* * *} \\
(7.98)\end{array}$ & $\begin{array}{l}-0.115^{* * * *} \\
(7.98)\end{array}$ & $\begin{array}{l}-0.119 * * * \\
(8.25)\end{array}$ & $\begin{array}{l}-0.122 * * * \\
(8.55)\end{array}$ \\
\hline Policy on welfare & & $\begin{array}{l}0.041 \\
(1.56)\end{array}$ & $\begin{array}{l}0.046^{*} \\
(1.77)\end{array}$ & $\begin{array}{l}0.046^{*} \\
(1.77)\end{array}$ & $\begin{array}{l}-0.035 \\
(1.24)\end{array}$ \\
\hline $\begin{array}{l}\text { Lagged recognition } \\
\text { rate }\end{array}$ & & & $\begin{array}{l}0.219 * * \\
(2.56)\end{array}$ & $\begin{array}{l}0.223^{* *} \\
(2.37)\end{array}$ & $\begin{array}{l}0.181 * * \\
(2.00)\end{array}$ \\
\hline $\begin{array}{l}\text { Readmission } \\
\text { agreement }\end{array}$ & & & & $\begin{array}{l}0.356^{*} \\
(1.85)\end{array}$ & $\begin{array}{l}0.364^{*} \\
(1.89)\end{array}$ \\
\hline $\begin{array}{l}\text { Lagged immigration } \\
\text { policy }\end{array}$ & & & & & $\begin{array}{l}0.022 * * \\
(2.12)\end{array}$ \\
\hline $\begin{array}{l}\text { Fixed effects } \\
\text { (number of FE) }\end{array}$ & $\begin{array}{l}\text { Origin } \times \\
\text { Year } \\
(862) \\
\end{array}$ & $\begin{array}{l}\text { Origin } \times \\
\text { Year } \\
(862)\end{array}$ & $\begin{array}{l}\text { Origin } \times \\
\text { Year } \\
(862)\end{array}$ & $\begin{array}{l}\text { Origin } \times \\
\text { Year } \\
(862)\end{array}$ & $\begin{array}{l}\text { Origin } \times \\
\text { Year } \\
(862)\end{array}$ \\
\hline $\begin{array}{l}\text { Destination } \\
\text { dummies }\end{array}$ & Yes & Yes & Yes & Yes & Yes \\
\hline Year dummies & No & No & No & No & No \\
\hline $\mathrm{R}^{2}$ Within & 0.413 & 0.416 & 0.417 & 0.419 & 0.420 \\
\hline No of Obs. & 10875 & 10875 & 10875 & 10875 & 10875 \\
\hline
\end{tabular}

Note: ' $\mathrm{z}$ ' statistics in parentheses from standard errors clustered by origin country; significance at 1,5 and 10 percent denoted by $* * *, * *$ and $*$ respectively. Constant terms and coefficients on destination dummies are not reported. 
Table 7: Predicted percentage change in asylum applications due to asylum policies

\begin{tabular}{|l|r|r|l|r|r|}
\hline & $1997-2005$ & $2005-2014$ & & $1997-2005$ & $2005-2014$ \\
\hline Australia & -56.2 & -4.4 & Italy & -28.3 & 20.0 \\
\hline Austria & -42.3 & 0.0 & Netherlands & -48.6 & -10.9 \\
\hline Belgium & -14.8 & -10.9 & Norway & -32.3 & -20.5 \\
\hline Canada & -18.2 & -32.3 & Poland & -14.8 & -4.4 \\
\hline Czech Rep. & -4.4 & 0.0 & Spain & -29.4 & -16.2 \\
\hline Denmark & -39.6 & 0.0 & Sweden & 0.0 & 103.4 \\
\hline France & -27.4 & 17.4 & Switzerland & -29.2 & -38.3 \\
\hline Germany & -7.1 & 2.9 & UK & -59.1 & -19.5 \\
\hline Hungary & 0.0 & -10.9 & USA & -27.4 & -21.3 \\
\hline Ireland & -42.3 & 0.0 & Total & -28.9 & 2.9 \\
\hline
\end{tabular}

Source: Author calculations based on coefficients from col. (2) of Table 6.

Table 8: Public opinion against refugees and immigrants 2002 and 2014 (percent)

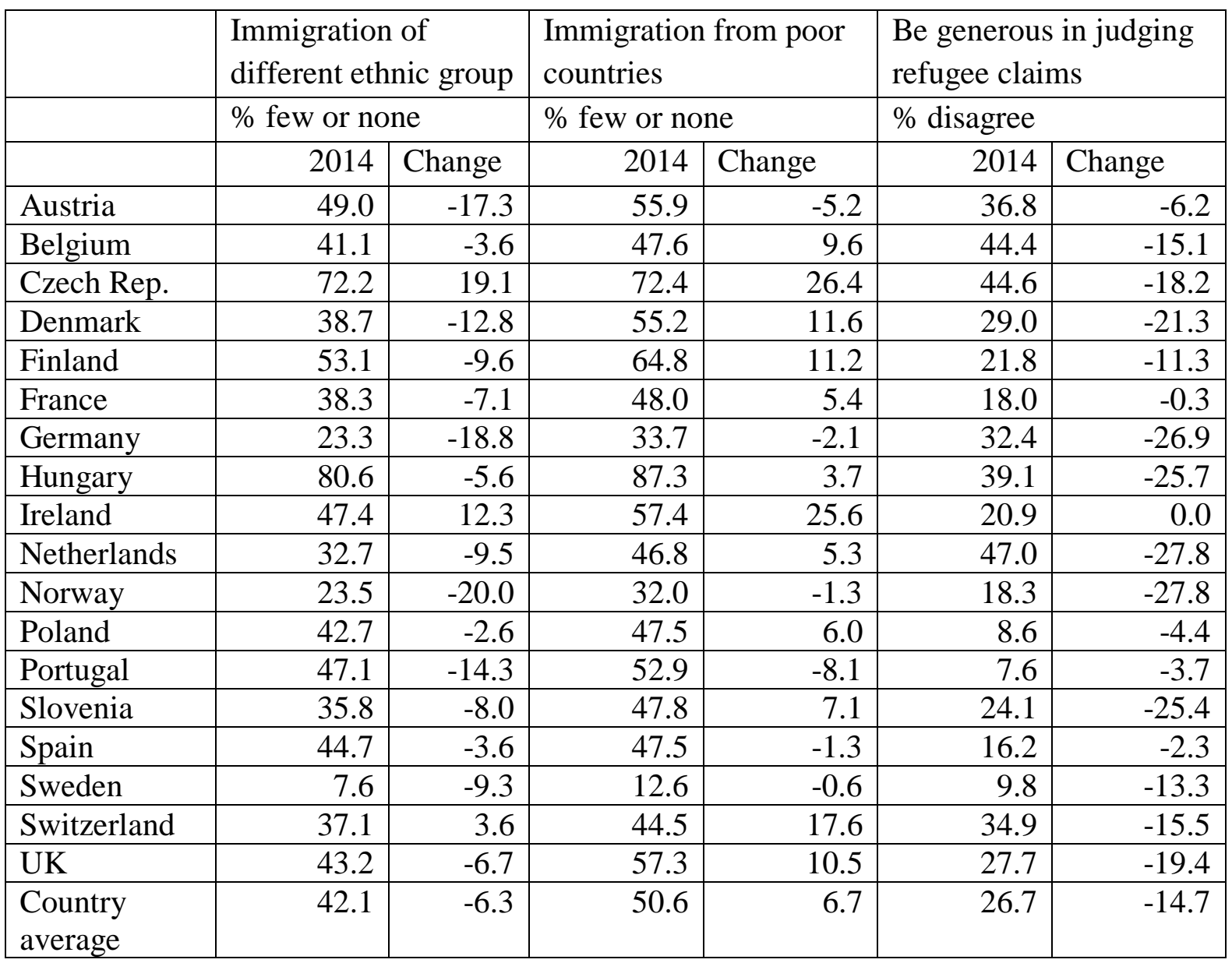

Source: European Social Survey, rounds 1 and 7. 
Table 9: Salience of immigration as a policy issue 2003-2015 (percent)

\begin{tabular}{|l|r|r|r|r|r|r|}
\hline & 2003 & 2007 & 2009 & 2011 & 2013 & 2015 \\
\hline Austria & 11.1 & 23.1 & 13.7 & 16.2 & 12.7 & 31.2 \\
\hline Belgium & 18.4 & 19.4 & 14.1 & 20.6 & 15.1 & 23.0 \\
\hline Czech Rep & & 4.6 & 3.9 & 3.5 & 2.4 & 18.0 \\
\hline Denmark & 21.5 & 21.8 & 11.8 & 9.5 & 13.7 & 35.4 \\
\hline Estonia & & 2.4 & 0.3 & 1.4 & 2.8 & 24.3 \\
\hline Finland & 5.2 & 5.3 & 8.7 & 7.4 & 4.6 & 5.9 \\
\hline France & 8.9 & 12.2 & 5.0 & 10.2 & 10.3 & 12.3 \\
\hline Germany & 6.4 & 6.7 & 3.9 & 7.0 & 15.5 & 46.8 \\
\hline Greece & 6.8 & 5.0 & 9.0 & 5.4 & 5.9 & 10.5 \\
\hline Hungary & & 1.6 & 0.7 & 0.5 & 1.6 & 13.1 \\
\hline Ireland & 5.9 & 12.9 & 3.0 & 5.6 & 8.0 & 7.3 \\
\hline Italy & 14.1 & 14.6 & 12.4 & 13.9 & 5.9 & 31.3 \\
\hline Luxembourg & 14.3 & 10.9 & 8.1 & 20.6 & 12.0 & 15.1 \\
\hline Netherlands & 8.8 & 14.1 & 6.6 & 10.8 & 3.9 & 22.9 \\
\hline Poland & & 8.8 & 1.9 & 1.1 & 3.1 & 9.0 \\
\hline Portugal & 3.0 & 2.0 & 1.2 & 0.6 & 0.9 & 2.6 \\
\hline Slovenia & & 2.5 & 1.0 & 0.7 & 0.5 & 1.2 \\
\hline Slovakia & & 2.7 & 1.2 & 0.5 & 0.8 & 3.9 \\
\hline Spain & 22.3 & 30.1 & 7.8 & 5.6 & 1.8 & 5.9 \\
\hline Sweden & 7.3 & 11.1 & 7.1 & 8.2 & 12.8 & 27.8 \\
\hline UK & 26.2 & 32.7 & 22.5 & 20.3 & 29.6 & 35.8 \\
\hline Country & 12.0 & 11.6 & 6.9 & 8.1 & 7.8 & 18.3 \\
Average & & & & & & \\
\hline
\end{tabular}

Source: Eurobarometer. Each year includes the autumn and spring rounds except the last, which is for May 2015.The rounds used are: 57.2 and 60.1 (2003), 66.1 and 67.2 (2007), 70.1 and 71.3 (2009), 74.2 and 75.3 (2011), 78.1 and 79.3 (2013), and 83.3 (2015).

Table 10: Public concerns about legal and illegal immigration (percent)

\begin{tabular}{|l|l|l|l|l|l|l|}
\hline & \multicolumn{3}{|l|}{ Worried about legal immigration } & \multicolumn{3}{l|}{ Worried about illegal immigration } \\
\hline & 2009 & 2011 & 2013 & 2009 & 2011 & 2013 \\
\hline France & 20.5 & 21.5 & 32.2 & 57.3 & 59.1 & 70.9 \\
\hline Germany & 30.4 & 24.9 & 29.4 & 63.9 & 55.6 & 72.1 \\
\hline Italy & 20.7 & 22.5 & 27.2 & 80.5 & 79.9 & 86.2 \\
\hline Netherlands & 31.2 & -- & 31.9 & 58.0 & -- & 69.1 \\
\hline Spain & 22.2 & 23.5 & 23.9 & 71.4 & 73.9 & 73.9 \\
\hline UK & 36.3 & 40.6 & 40.6 & 68.0 & 70.9 & 80.2 \\
\hline
\end{tabular}

Source: Transatlantic Trends-Immigration 2009 and 2011; Transatlantic Trends 2013. The survey is based on telephone interviews with an average of a thousand respondents in each country; the figures here are calculated using the sociodemographic weights. Data kindly supplied by Inter-University Consortium for Political and Social Research. 
Table 11: Percent in favour of EU-level decision-making on asylum and immigration policy

\begin{tabular}{|c|c|c|c|c|c|}
\hline & Asylum & Immigration & Immigration & Immigration & $\begin{array}{l}\text { Immig } \\
\text { Policy }\end{array}$ \\
\hline & Spring 2000 & Spring 2000 & $\begin{array}{l}\text { Autumn } \\
2005\end{array}$ & $\begin{array}{l}\text { Autumn } \\
2010\end{array}$ & Spring 2015 \\
\hline Austria & 25.9 & 23.5 & 42.0 & 39.0 & 58.2 \\
\hline Belgium & 58.0 & 57.4 & 67.2 & 72.4 & 76.1 \\
\hline Bulgaria & & & 67.1 & 81.4 & 77.9 \\
\hline Cyprus & & & 63.1 & 67.9 & 75.8 \\
\hline Czech Rep & & & 57.1 & 56.5 & 50.7 \\
\hline Denmark & 33.1 & 31.3 & 45.4 & 48.3 & 63.2 \\
\hline Estonia & & & 48.2 & 52.9 & 50.0 \\
\hline Finland & 27.3 & 14.0 & 17.0 & 29.2 & 56.4 \\
\hline France & 55.9 & 56.1 & 69.9 & 74.6 & 72.3 \\
\hline Germany & 44.7 & 43.1 & 57.3 & 65.4 & 82.3 \\
\hline Greece & 41.9 & 40.0 & 54.1 & 52.0 & 70.1 \\
\hline Hungary & & & 67.0 & 67.0 & 67.8 \\
\hline Ireland & 36.9 & 34.9 & 56.4 & 61.1 & 74.4 \\
\hline Italy & 71.3 & 69.4 & 67.1 & 75.8 & 81.8 \\
\hline Latvia & & & 65.8 & 70.2 & - \\
\hline Lithuania & & & 69.5 & 70.2 & 84.5 \\
\hline Luxembourg & 45.8 & 44.9 & 55.0 & 63.5 & 65.3 \\
\hline Malta & & & 69.3 & 82.5 & 83.9 \\
\hline Netherlands & 73.2 & 70.0 & 54.7 & 64.6 & 84.4 \\
\hline Poland & & & 71.9 & 69.2 & 65.3 \\
\hline Portugal & 36.2 & 37.3 & 60.8 & 70.1 & 71.7 \\
\hline Romania & & & 71.3 & 72.1 & 77.7 \\
\hline Slovakia & & & 65.8 & 69.0 & 64.4 \\
\hline Slovenia & & & 65.8 & 66.8 & 68.3 \\
\hline Spain & 59.7 & 59.8 & 72.8 & 68.5 & 81.3 \\
\hline Sweden & 35.9 & 31.3 & 32.6 & 49.6 & 79.1 \\
\hline UK & 24.6 & 25.3 & 40.7 & 39.1 & 59.9 \\
\hline EU-15 & 44.7 & 42.6 & 52.9 & 58.2 & 71.8 \\
\hline EU-27 & & & 57.5 & 61.8 & 70.3 \\
\hline
\end{tabular}

Source: Eurobarometer rounds 53 (2000), 64.2 (2005), 74.2 (2010), and 83.3 (2015). 
Table 12: Percentage in favour of additional measures to fight illegal immigration, May 2015

\begin{tabular}{|c|c|c|c|c|c|}
\hline & (1) & (2) & (3) & (4) & (5) \\
\hline & $\begin{array}{l}\text { At national } \\
\text { level }\end{array}$ & At EU level & $\begin{array}{l}\text { At EU and } \\
\text { national } \\
\text { level }\end{array}$ & Total & $\begin{array}{l}\text { Change since } \\
2014\end{array}$ \\
\hline Austria & 29.1 & 17.4 & 42.7 & 89.2 & 10.2 \\
\hline Belgium & 18.6 & 43.3 & 28.6 & 90.5 & 1.1 \\
\hline Bulgaria & 21.5 & 22.1 & 45.9 & 89.4 & 3.4 \\
\hline Cyprus & 26.0 & 17.3 & 50.7 & 94.0 & 0.8 \\
\hline Czech Rep & 32.3 & 33.6 & 27.3 & 93.3 & 3.0 \\
\hline Denmark & 13.9 & 41.8 & 34.8 & 90.4 & 4.7 \\
\hline Estonia & 12.8 & 16.3 & 62.9 & 91.9 & 6.2 \\
\hline Finland & 16.1 & 37.2 & 34.4 & 87.7 & 0.6 \\
\hline France & 15.1 & 32.4 & 32.0 & 79.6 & 0.8 \\
\hline Germany & 10.4 & 29.8 & 46.7 & 86.9 & 5.8 \\
\hline Greece & 34.4 & 26.1 & 37.9 & 98.4 & 1.7 \\
\hline Hungary & 25.4 & 20.2 & 45.5 & 91.1 & 4.6 \\
\hline Ireland & 23.8 & 21.9 & 42.9 & 88.6 & 2.9 \\
\hline Italy & 22.5 & 30.8 & 40.1 & 93.4 & 2.7 \\
\hline Latvia & 15.0 & 24.7 & 41.9 & 81.7 & 1.5 \\
\hline Lithuania & 20.0 & 31.0 & 35.6 & 86.5 & 8.3 \\
\hline Luxembourg & 7.2 & 35.0 & 47.7 & 89.9 & 2.6 \\
\hline Malta & 11.6 & 27.0 & 57.3 & 95.9 & 0.3 \\
\hline Netherlands & 7.3 & 37.3 & 43.2 & 87.8 & 3.1 \\
\hline Poland & 22.5 & 24.4 & 34.2 & 81.0 & 14.4 \\
\hline Portugal & 23.9 & 31.4 & 36.6 & 91.9 & 9.0 \\
\hline Romania & 20.9 & 27.3 & 24.0 & 72.1 & 0.2 \\
\hline Slovakia & 30.1 & 23.7 & 32.4 & 86.1 & -1.2 \\
\hline Slovenia & 17.8 & 27.4 & 31.8 & 77.0 & 2.4 \\
\hline Spain & 16.8 & 37.5 & 30.3 & 84.5 & -0.8 \\
\hline Sweden & 8.1 & 32.6 & 35.0 & 75.8 & 7.1 \\
\hline UK & 28.3 & 21.4 & 32.6 & 82.2 & -2.6 \\
\hline EU15 & 18.1 & 31.5 & 38.1 & 87.7 & 3.3 \\
\hline EU27 & 19.5 & 28.4 & 39.3 & 87.3 & 3.4 \\
\hline
\end{tabular}

Source: Eurobarometer 83.3 (2015) and 82.3 (2014). See also

http://ec.europa.eu/public_opinion/archives/eb/eb83/eb83 anx_en.pdf 
Table 13: Unauthorised border crossings by migratory route 2006-2015

\begin{tabular}{|r|r|l|r|r|r|r|r|r|}
\hline Year & $\begin{array}{l}\text { West } \\
\text { Africa }\end{array}$ & $\begin{array}{l}\text { West } \\
\text { Med }\end{array}$ & $\begin{array}{l}\text { Central } \\
\text { Med }\end{array}$ & $\begin{array}{l}\text { Albania- } \\
\text { Greece }\end{array}$ & $\begin{array}{l}\text { West } \\
\text { Balkans }\end{array}$ & $\begin{array}{l}\text { Eastern } \\
\text { Med }\end{array}$ & $\begin{array}{l}\text { Eastern } \\
\text { Borders }\end{array}$ & Total \\
\hline 2006 & 31600 & & & & & & & \\
\hline 2007 & 12500 & & & & & & & \\
\hline 2008 & 9200 & 6500 & 39800 & 42000 & & 52300 & 1335 & 151135 \\
\hline 2009 & 2250 & 6650 & 11807 & 40000 & 3090 & 40000 & 1050 & 164697 \\
\hline 2010 & 200 & 5000 & 7288 & 35300 & 2370 & 55700 & 1050 & 106908 \\
\hline 2011 & 340 & 8450 & 69559 & 5300 & 4650 & 5700 & 1050 & 95049 \\
\hline 2012 & 170 & 6400 & 163772 & 5500 & 6390 & 37200 & 1600 & 221032 \\
\hline 2013 & 250 & 6800 & 40500 & 8700 & 19950 & 24800 & 1300 & 102300 \\
\hline 2014 & 278 & 7840 & 170760 & 8840 & 43360 & 50830 & 1270 & 283178 \\
\hline 2015 & 874 & 7104 & 153946 & 8932 & 764083 & 885386 & 1290 & 1821615 \\
\hline
\end{tabular}

Source: Frontex at: http://frontex.europa.eu/trends-and-routes/migratory-routes-map/. 


\section{Appendix 1: Data Sources}

\section{Determinants of asylum applications:}

\section{Bilateral variables}

Asylum applications: Applications are taken from the UNHCR's Statistical Online Population Database at: http://www.unhcr.org/pages/4a013eb06.html; supplemented for earlier years from the UNHCR's annual report on Asylum Levels and Trends in Industrialized Countries.

Immigrant stock: The number of immigrants aged 25 or over from each source at each destination in 2000/1 are taken from version 2 of the database at the website of Frederic Docquier: http://perso.uclouvain.be/frederic.docquier/oxlight.htm.

Distance: Great circle distance between capital cities (in $\mathrm{km}$ ) from the website of Kristian Skrede Gleditsch: at: http://privatewww.essex.ac.uk/ ksg/data-5.html.

Readmission agreements: Data on readmission agreements for European countries kindly provided by Jean-Pierre Cassarino. A dummy variable is based on the dates that these agreements cane into force, including the transposition of EU readmission agreements into national law.

Countries in the dataset

\begin{tabular}{|l|l|l|l|}
\hline Destination & & & \\
\hline Australia & Finland & Italy & Slovenia \\
\hline Austria & France & Netherlands & Spain \\
\hline Belgium & Germany & Norway & Sweden \\
\hline Canada & Greece & Poland & Switzerland \\
\hline Czech Rep. & Hungary & Portugal & UK \\
\hline Denmark & Ireland & Slovakia & USA \\
\hline Origin & & & \\
\hline Afghanistan & Cuba & Iran (Islamic Rep) & Russian Federation \\
\hline Albania & Dem. Rep. Congo & Iraq & Rwanda \\
\hline Algeria & Egypt & Lebanon & Senegal \\
\hline Angola & El Salvador & Liberia & Sierra Leone \\
\hline Armenia & Eritrea & Libya & Somalia \\
\hline Azerbaijan & Ethiopia & Mali & Sri Lanka \\
\hline Bangladesh & Gambia & Mauritania & Sudan \\
\hline Belarus & Georgia & Mexico & Syrian Arab Rep. \\
\hline $\begin{array}{l}\text { Bosnia \& } \\
\text { Herzegovina }\end{array}$ & Ghana & Mongolia & Togo \\
\hline Bulgaria & Guatemala & Morocco & Tunisia \\
\hline Côte d'Ivoire & Guinea & Nepal & Turkey \\
\hline Cameroon & Haiti & Nigeria & Ukraine \\
\hline China & Honduras & Pakistan & Viet Nam \\
\hline Colombia & India & Rep. of Moldova & Yugo \\
\hline Congo & Indonesia & Romania & Zimbabwe \\
\hline
\end{tabular}


Political terror scale: Taken from the website of Mark Gibney at:

http://www.politicalterrorscale.org/. The variable used is the average of the values derived from the reports of US State Department and Amnesty International.

Battle deaths: The number of battle-related deaths in conflicts from the UCDP Battle-related Deaths Dataset V5-2015, at: http://www.pcr.uu.se/research/ucdp/datasets/ucdp_battlerelated_deaths_dataset/. The figure used is either the 'best estimate' or the average of high and low figures.

Freedom House indices: Indices for political rights and civil liberties from: http://www.freedomhouse.org/report-types/freedom-world\#.

Real GDP per capita: Taken from version 7.1 of the Penn world Tables (rgdpch) at: https://pwt.sas.upenn.edu/php_site/pwt71/pwt71_form.php (chosen in preference to PWT V8 because of the country coverage. Data for the year 2011-14 and other missing values from the IMF at: http://www.imf.org/external/data.htm.

\section{Destination country variables}

Real GDP per capita: Taken from OECD at: http://stats.oecd.org/.

Unemployment rate: OECD harmonised unemployment rate (all persons) from: http://stats.oecd.org/.

Policy index: Own calculations. For (some) further details, see Hatton and Moloney (2015).

Recognition rate: From UNHCR Statistical Yearbook, 2005 (Annex C13) and UNHCR Global Trends, 2006-14 (Table 10).

Immigration policy: Constructed from DEMIG (2015) DEMIG POLICY, version 1.3, Online Edition. Oxford: International Migration Institute, University of Oxford at:

http://www.imi.ox.ac.uk/data/demig-data/demig-policy-1. The components of policy used here are those related work visa, quota or target, points system, recruitment/assisted migration, regularisation. The weighting is: 0.25 for 'fine tuning', 0.5 for 'minor change' 0.75 for mid-level change and 1 for major change; positive for changes that are more restrictive and negative those that are less restrictive. 
Means and standard deviations of variables; 10,875 observations

\begin{tabular}{|l|l|l|}
\hline Asylum applications by destination per 1000 of origin popn. & 0.046 & 0.146 \\
\hline Political terror scale, origin country & 3.486 & 1.003 \\
\hline Freedom House index of civil liberties, origin country & 4.743 & 1.330 \\
\hline Freedom House index of political rights, origin country & 4.929 & 1.619 \\
\hline Battle deaths per 1000 origin country population & 0.042 & 0.304 \\
\hline Real GDP per capita in origin countries in \$US (2011) & 4022.7 & 3461.8 \\
\hline Migrant stock by destination per 1000 of origin population & 1.396 & 6.179 \\
\hline Distance in kilometres from origin to destination & 5577.2 & 3275.9 \\
\hline Real GDP per capita in destination countries in \$US $(2011)$ & 34052.3 & 9563.7 \\
\hline Unemployment rate in destination countries & 7.085 & 3.347 \\
\hline Total policy index for destination countries $(1997 q 1=0)$ & 2.705 & 3.265 \\
\hline Policy on access in destination countries $(1997 q 1=0)$ & 0.958 & 1.016 \\
\hline Policy on processing in destination countries $(1997 q 1=0)$ & 1.009 & 1.806 \\
\hline Policy on welfare in destination countries $(1997 q 1=0)$ & 0.738 & 1.446 \\
\hline Total refugee recognition rate destination countries & 0.322 & 0.189 \\
\hline Immigration policy index, employment stream $(1997=0)$ & -3.751 & 3.548 \\
\hline
\end{tabular}

\section{Public opinion data}

European Social Survey: From: http://www.europeansocialsurvey.org/data/.

Eurobarometer: Standard Eurobarometer at: http://zacat.gesis.org/webview/.

Transatlantic Trends: Data kindly supplied by Inter-University Consortium for Political and Social Research. 


\section{Appendix 2: Analysis of the ESS for 2002 and 2014 (updated)}

The ESS data for changes in preferences over immigration and attitudes to refugees are plotted by for 18 countries in Figure 5. Regression analysis on individual level data for the same 18 countries is presented in the table below. The table reports marginal probabilities from probit regressions on the pooled data for 2002 and 2014. The data excludes those aged less than 18 and over 100. The education groups are based on years of education, where 'high' is greater than 15 years, 'middle' is 12-15 years and cases with years greater than 22 are excluded.

\begin{tabular}{|c|c|c|c|c|c|c|}
\hline & (1) & (2) & (3) & (4) & (5) & (6) \\
\hline & \multicolumn{2}{|c|}{$\begin{array}{l}\text { Immigration of } \\
\text { different ethnic group }\end{array}$} & \multicolumn{2}{|c|}{$\begin{array}{l}\text { Immigration from } \\
\text { poor countries }\end{array}$} & \multicolumn{2}{|c|}{$\begin{array}{l}\text { Be generous in } \\
\text { judging refugee claims }\end{array}$} \\
\hline Age 18 to 35 & $\begin{array}{l}-0.037 * * * \\
(-3.44)\end{array}$ & $\begin{array}{l}-0.038 * * * \\
(-3.53)\end{array}$ & $\begin{array}{l}-0.038 * * * \\
(-3.58) \\
\end{array}$ & $\begin{array}{l}-0.039 * * * \\
(-3.68)\end{array}$ & $\begin{array}{l}-0.022 * * \\
(-2.56)\end{array}$ & $\begin{array}{l}-0.022 * * \\
(-2.56) \\
\end{array}$ \\
\hline Age 55 plus & $\begin{array}{l}0.047 * * * \\
(5.12)\end{array}$ & $\begin{array}{l}0.048 * * * \\
(5.09)\end{array}$ & $\begin{array}{l}0.053 * * * \\
(6.38)\end{array}$ & $\begin{array}{l}0.053 * * * \\
(6.32)\end{array}$ & $\begin{array}{l}-0.005 \\
(-0.46)\end{array}$ & $\begin{array}{l}-0.005 \\
(-0.46)\end{array}$ \\
\hline Male & $\begin{array}{l}0.009 \\
(1.10)\end{array}$ & $\begin{array}{l}0.010 \\
(1.11)\end{array}$ & $\begin{array}{l}0.018 * \\
(1.91)\end{array}$ & $\begin{array}{l}0.018^{*} \\
(1.91)\end{array}$ & $\begin{array}{l}0.040 * * * \\
(5.95)\end{array}$ & $\begin{array}{l}0.040 * * * \\
(5.96)\end{array}$ \\
\hline $\begin{array}{l}\text { Labour force } \\
\text { participant }\end{array}$ & $\begin{array}{l}-0.005 \\
(-0.77)\end{array}$ & $\begin{array}{l}-0.005 \\
(-0.73)\end{array}$ & $\begin{array}{l}-0.009 \\
(-1.30)\end{array}$ & $\begin{array}{l}-0.009 \\
(-1.24)\end{array}$ & $\begin{array}{l}0.029 * * * \\
(5.28)\end{array}$ & $\begin{array}{l}0.029 * * * \\
(5.28)\end{array}$ \\
\hline High education & $\begin{array}{l}-0.264 * * * \\
(-24.81)\end{array}$ & $\begin{array}{l}-0.264 * * * \\
(-25.29)\end{array}$ & $\begin{array}{l}-0.242 * * * \\
(-21.88)\end{array}$ & $\begin{array}{l}-0.242 * * * \\
(-22.30)\end{array}$ & $\begin{array}{l}-0.102 * * * \\
(-7.16)\end{array}$ & $\begin{array}{l}-0.102 * * * \\
(-7.17)\end{array}$ \\
\hline $\begin{array}{l}\text { Middle } \\
\text { education }\end{array}$ & $\begin{array}{l}-0.123 * * * \\
(-12.32)\end{array}$ & $\begin{array}{l}-0.123 * * * \\
(-12.29)\end{array}$ & $\begin{array}{l}-0.103 * * * \\
(-10.98)\end{array}$ & $\begin{array}{l}-0.102 * * * \\
(-10.95)\end{array}$ & $\begin{array}{l}-0.030 * * * \\
(-2.92)\end{array}$ & $\begin{array}{l}-0.030 * * * \\
(-2.92)\end{array}$ \\
\hline Year 2014 & $\begin{array}{l}-0.060 * * \\
(-2.11)\end{array}$ & $\begin{array}{l}-0.080 * * * \\
(-3.59)\end{array}$ & $\begin{array}{l}0.039 \\
(1.53)\end{array}$ & $\begin{array}{l}0.021 \\
(1.01)\end{array}$ & $\begin{array}{l}-0.158 * * * \\
(-7.04)\end{array}$ & $\begin{array}{l}-0.158 * * * \\
(-6.91)\end{array}$ \\
\hline $\begin{array}{l}\text { Asylum } \\
\text { apps/population }\end{array}$ & & $\begin{array}{l}0.012 * * * \\
(2.60)\end{array}$ & & $\begin{array}{l}0.011 * * * \\
(2.64)\end{array}$ & & $\begin{array}{l}0.000 \\
(0.01)\end{array}$ \\
\hline Cntry dummies & Yes & Yes & Yes & Yes & Yes & Yes \\
\hline Pseudo $\mathrm{R}^{2}$ & 0.105 & 0.107 & 0.098 & 0.099 & 0.110 & 0.110 \\
\hline Observations & 61,271 & 61,271 & 61,086 & 61,086 & 61,064 & 61,064 \\
\hline
\end{tabular}

Note: ' $\mathrm{t}$ ' statistics based on standard errors clustered by country; significance at 1,5 and 10 percent denoted by $* * *, * *$ and $*$.

Columns (1) to (4) show that anti-immigration preferences are increasing across age groups and decreasing across education groups. For the question on refugees, columns (5) and (6) show that the age and education gradients are much less steep. However the effects of gender and labour force participation are stronger. Columns (1), (3) and (5) show that a dummy for 2014 produces estimates of change over time similar to the country averages reported in Table 8. In column (6) the fall in anti-refugee sentiment is highly significant. As shown in columns (2), (4) and (6), the average number of asylum applicants in the preceding five years takes significant positive coefficients for the two groups of immigrants, raising anti-immigrant preferences but it has no effect on preferences over generosity towards refugees. 


\section{BOX 1: Australian Policy and Irregular Maritime Arrivals}

In the late 1990s there was a growing number of irregular boat arrivals on Australia's northern shore and outlying islands. Events came to a head in September 2001 with the arrival off Christmas Island of a Norwegian freighter, the MV Tampa, which had taken on board 433 asylum seekers when their vessel had got into distress in the open seas. The Tampa was initially refused permission to land the asylum seekers and there followed a week-long standoff until an agreement was reached by which a third of the passengers was taken to New Zealand and the remainder to Nauru, a Pacific microstate. A month later the Australian government passed six new bills into law. The first two involved the excision of several islands as Australian territory for the purposes of establishing claims to asylum, and provided for boat arrivals to be processed offshore in Nauru and Papua New Guinea (PNG). Further measures included mandatory detention, tightening eligibility for recognition, and abbreviating the processing of asylum claims. The penalties for people smuggling were increased and the Australia coastguard was authorised to turn back unauthorised boats. This became known as the Pacific Solution.

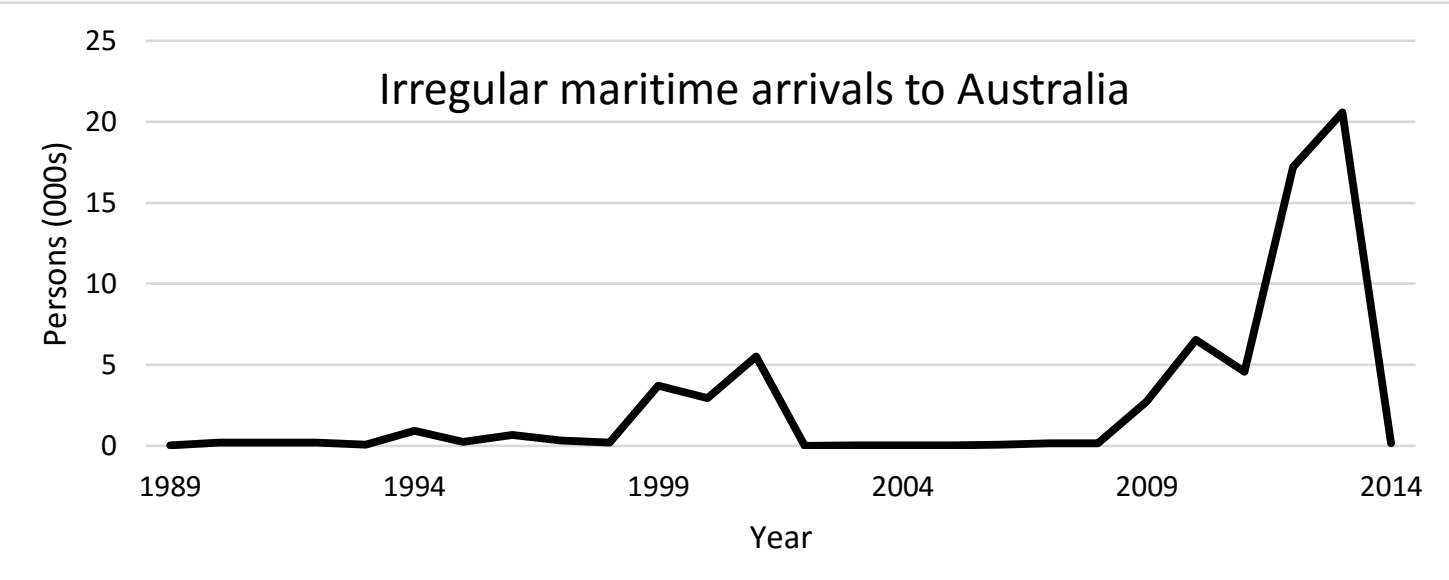

Source: Phillips (2015), Table 1.

The result of these draconian measures was that arrivals returned to very low levels from 2002 to 2007. Only five boats were turned back, the last in November 2003. Some of the elements of this regime were later relaxed, and some of the detainees gained residence in Australia. In 2007 the incoming government terminated offshore processing on Nauru and Manus Island (PNG). From 2008 temporary visas were replaced with permanent residence permits, and from 2009 detention was used only as a last resort. Boat arrivals increased steeply from 2009 creating a crisis for the government. In 2010 processing was suspended for boat arrivals from Afghanistan and Sri Lanka, who had formed a majority of those reaching Christmas Island. The new government of 2013 pledged to toughen border controls and to 'push back the boats', to reintroduce temporary protection visas, and to introduce a fast track status determination procedure. The policy stance largely reverted to that of 2001, and in some respects was even tougher. The number of arrivals fell dramatically between 2013 and 2014. Under Operation Sovereign Borders 20 boats were pushed back between December 2013 and July 2015 (Phillips, 2015, Table 4). 


\section{BOX 2: Syrians in Turkey}

In 2015 Turkey became the world's largest refugee host country. It is estimated that by the end of 2015 there were around 3 million Syrians in Turkey, making up 5 percent of the population. Most of the displaced Syrians are located in places close to the border. There are 22 refugee camps with a capacity for 220,000 refugees and so most Syrians live outside the camps, often in crowded accommodation or in makeshift shelters on the edges of towns. The concentration in border regions involves a number of challenges, not just for the Syrians but also for their Turkish hosts.

Around half of all Syrians in Turkey are under 18 and among the adults more than half are women (Erdoğan 2014). Various NGOs provide services and assistance to them but the bulk of the support for food, clothing and social services comes from the Turkish government. As of March 2016 the EU had not provided the $€ 3$ billion that was promised at a summit on $29^{\text {th }}$ November 2015. Apart from accommodation, the greatest need is for health care and education. Only about 15-20 percent of school-age children are attending school. Syrians in Turkey have temporary protection rather than refugee status and thus they are not permitted to work. As a result Syrians are employed almost exclusively in the informal sector.

Econometric studies have estimated the effects of the influx of Syrians in 2011-13 on local labour markets, exploiting distance from the border for identification (Del Carpio and Wagner 2015; Tumen. 2016). One effect of the Syrian influx on Turkish workers is displacement from informal jobs, mostly affecting females, younger and less educated workers. But there is some evidence of occupational upgrading to the formal sector. So, although informal sector wages fell, the average wage did not. Prices of goods produced by the informal sector fell by 4 percent, reflecting the labour influx. On the other hand average rents increased by 5.5 percent.

Survey evidence indicates that the Turkish population accords a high degree of social acceptance to the Syrians although stopping short of supporting full integration (Erdoğan 2014). Nevertheless they harbour concerns, principally about increasing rents, fear of losing jobs, and disruptions in access to public services, mainly healthcare. The Syrians express gratitude to Turkey although most would prefer eventually to return to Syria. In the short term one of the most pressing issues is their status as 'guests', which restricts access to the formal labour market. The other is lack of educational opportunities for their children. 


\section{BOX 3: Refuge-hosting as a public good}

The following model is set out in Hatton (2015a) pp 607-8. There are two host countries, the citizens of which derive value from refugees in their own country and from those in the other country, but the cost of hosting refugees falls only on the country that hosts them. The net valuations are described by:

$V_{1}=\alpha r_{1}-\beta r_{1}^{2}+\lambda r_{2}-c r_{1} ; \quad V_{2}=\alpha r_{2}-\beta r_{2}^{2}+\lambda r_{1}-c r_{2}$

Country 1 's valuation, $V_{1}$, depends the number of refugees that it hosts, $r_{1}$, which is represented by a quadratic function of the number of refugees in order to reflect eventually diminishing tolerance for refugees locally. It also depends positively on the number of refugees that find a safe haven in country $2, r_{2}$, and negatively on the cost of refugees in country $1, c r_{1}$. Country 2's valuation is described by an identical function with the same cost per refugee. In order to ensure that a positive number of refugees is chosen I assume that $\alpha>c$.

The number of refugees depends on the overall 'demand' for asylum (arising from conditions in source and transit countries), on the destination preference of asylum seekers, and on each country's asylum policy.

$r_{1}=A s \gamma_{1} ; \quad r_{2}=A(1-s) \gamma_{2}$

Where $A$ is the total demand, $s$ is the share of asylum seekers preferring country 1 , and $\gamma(0<\gamma<1)$ reflects the country's asylum policy, where higher values represent a more open or 'generous' policy. Tougher policies, as reflected by lower $\gamma$ deter asylum seekers either directly or indirectly. Thus the total number of refugees admitted, $R$, depends on total demand and a weighted average of policy.

$R=r_{1}+r_{2}=A\left[s \gamma_{1}+(1-s) \gamma_{2}\right]$

If each country chooses a policy to maximise its valuation independently of the other country, the non-cooperative policy settings are:

$\gamma_{1}^{N}=\frac{\alpha-c}{2 \beta A s} ; \quad \gamma_{2}^{N}=\frac{\alpha-c}{2 \beta A(1-s)}$

Thus a country's policy is tougher the higher is overall demand, the more that country is preferred as a destination, and the greater is the cost of refugees. Here both countries take the same number of refugees, $(\alpha-c) / 2 \beta$, but their policies differ.

In (4) the policies selected by each country take no account of the value of their refugees to the other country. The social optimum is obtained by maximising the sum of the two countries' valuations, $V_{1}+V_{2}$. This gives policy settings:

$\gamma_{1}^{*}=\frac{\alpha-c+\lambda}{2 \beta A s} ; \quad \gamma_{2}^{*}=\frac{\alpha-c+\lambda}{2 \beta A(1-s)}$

Asylum policies are more generous for both countries when the public good effects are taken into account through cooperative policy setting. In the social optimum the two countries still have different policies as a result of the difference in asylum seeker preferences. Each country now takes $(\alpha-c+\lambda) / 2 \beta$ refugees so the total number of admitted, $R$, is higher by an amount $\lambda / \beta$. 
Figure 1: Refugees and Asylum Seekers, 1982-2015

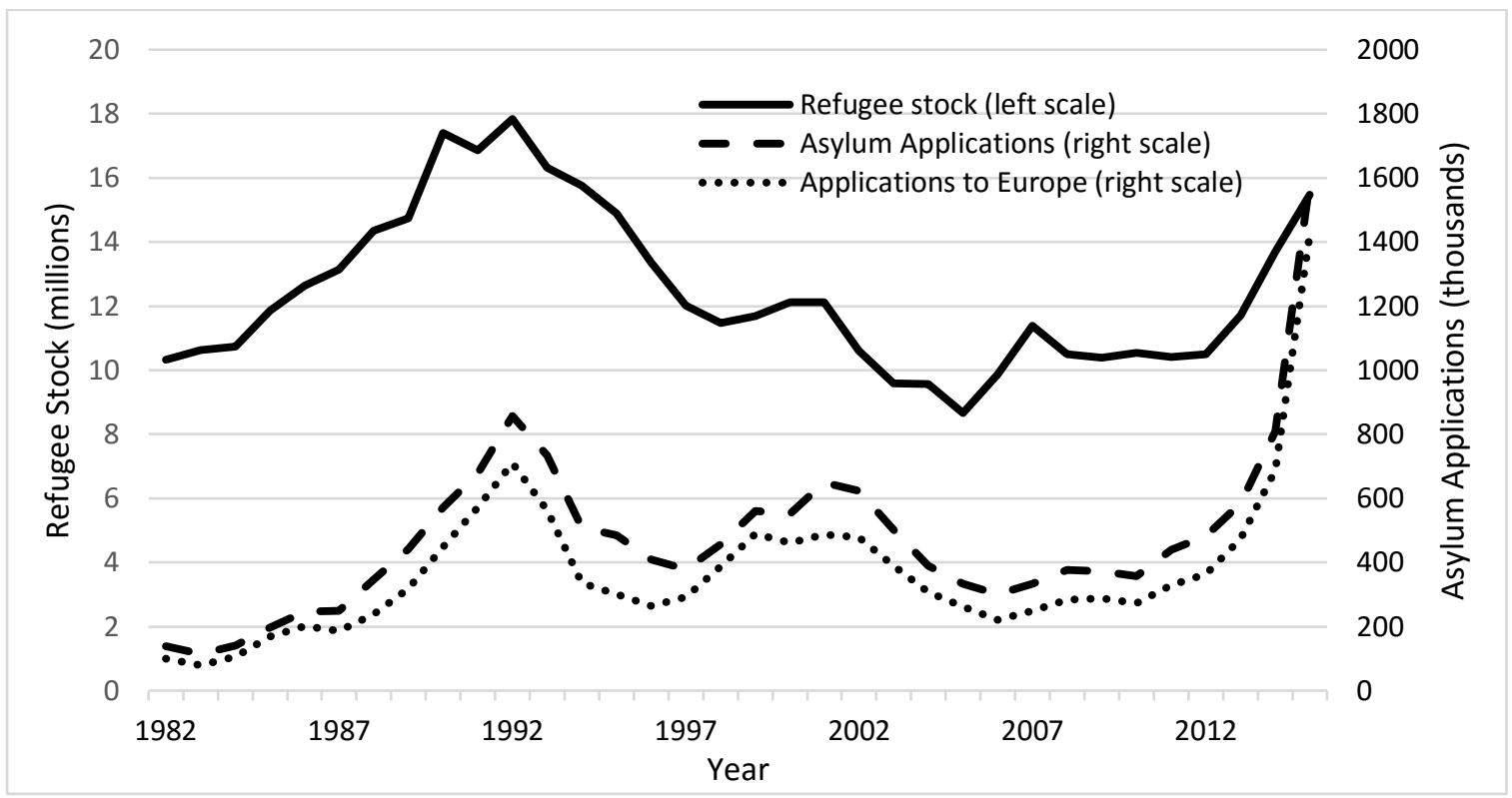

Sources: Refugee stock: UNHCR, “Total Refugee population by country of asylum, 1960-2013 \& Total Refugee population by origin, 1960-2013," at: http://www.unhcr.org/pages/49c3646c4d6.html, and UNHCR Global Trends, 2014 and 2015 Annex Table 1. Asylum applications to 'industrialized countries'; 1989-2000 from UNHCR Statistical Yearbook, 2001, Table C1; 2001-14 from UNHCR Asylum Levels and Trends in Industrialized Countries, 2005, 2009, 2013 and 2015, Table 1.

\section{Figure 2: Annual asylum Applications to the EU by Origin Country}

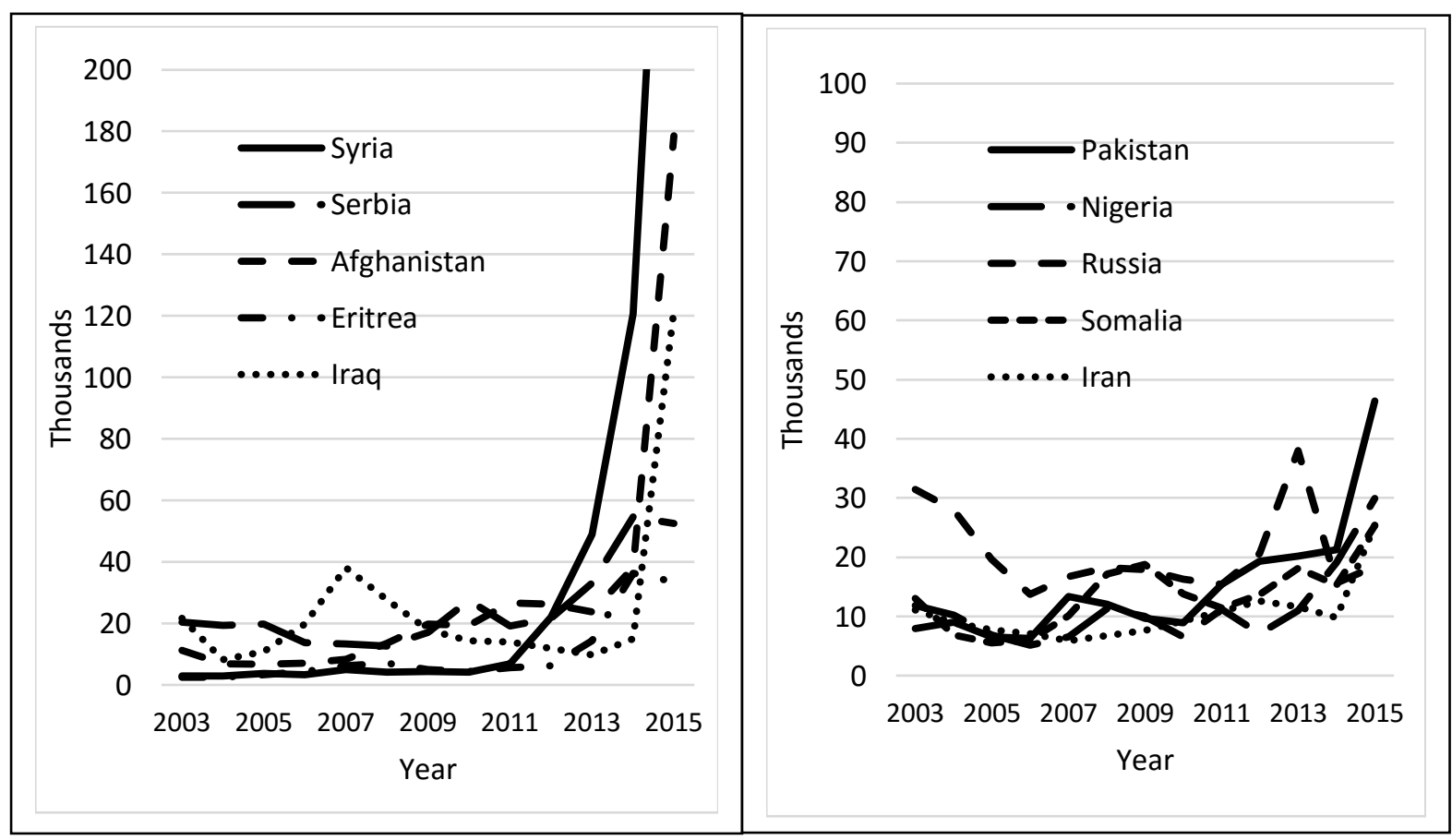

Source: UNHCR Asylum Levels and Trends in Industrialized Countries, 2004 to 2014, Table 4 and monthly update for 2015. 
Figure 3: Convention and total recognition rates, 20 European countries, 1982-2015

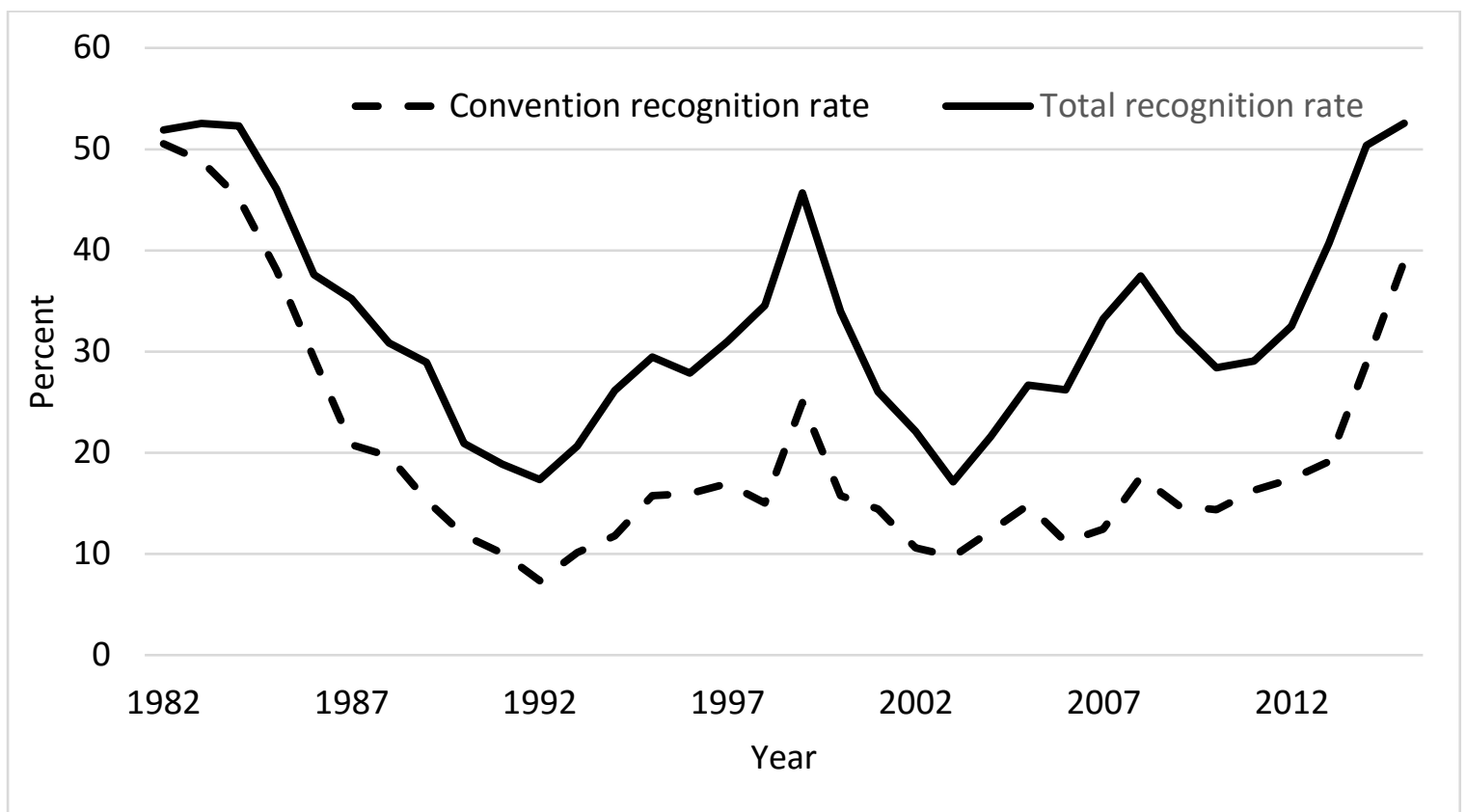

Source: Calculated from UNHCR Statistical Yearbooks, 2001 (Annexes C27 and 28) and 2005 (Annex C13) and UNHCR Global Trends,2006-15 (Table 10). This is a weighted average of recognition rates for the EU-15 plus the Czech Republic, Hungary, Norway, Poland and Switzerland.

Figure 4: Trends in policy and its components

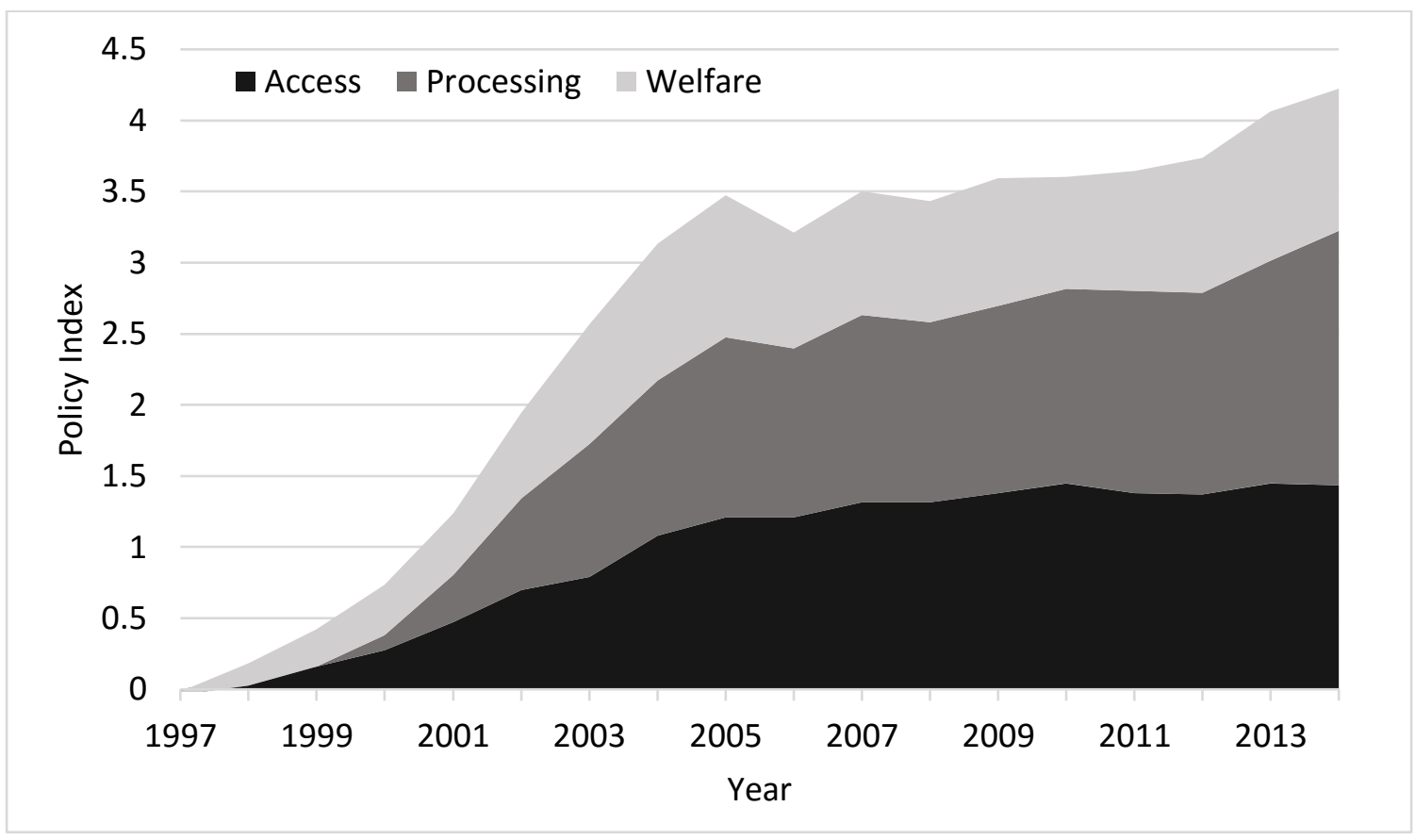

Source: Author calculations. These are averages of policy components for 19 countries equally weighted and stacked up to form the total index. 
Figure 5: Change in opinion 2002 to 2014 and change in asylum applications 1997-2002 to 2009-2014
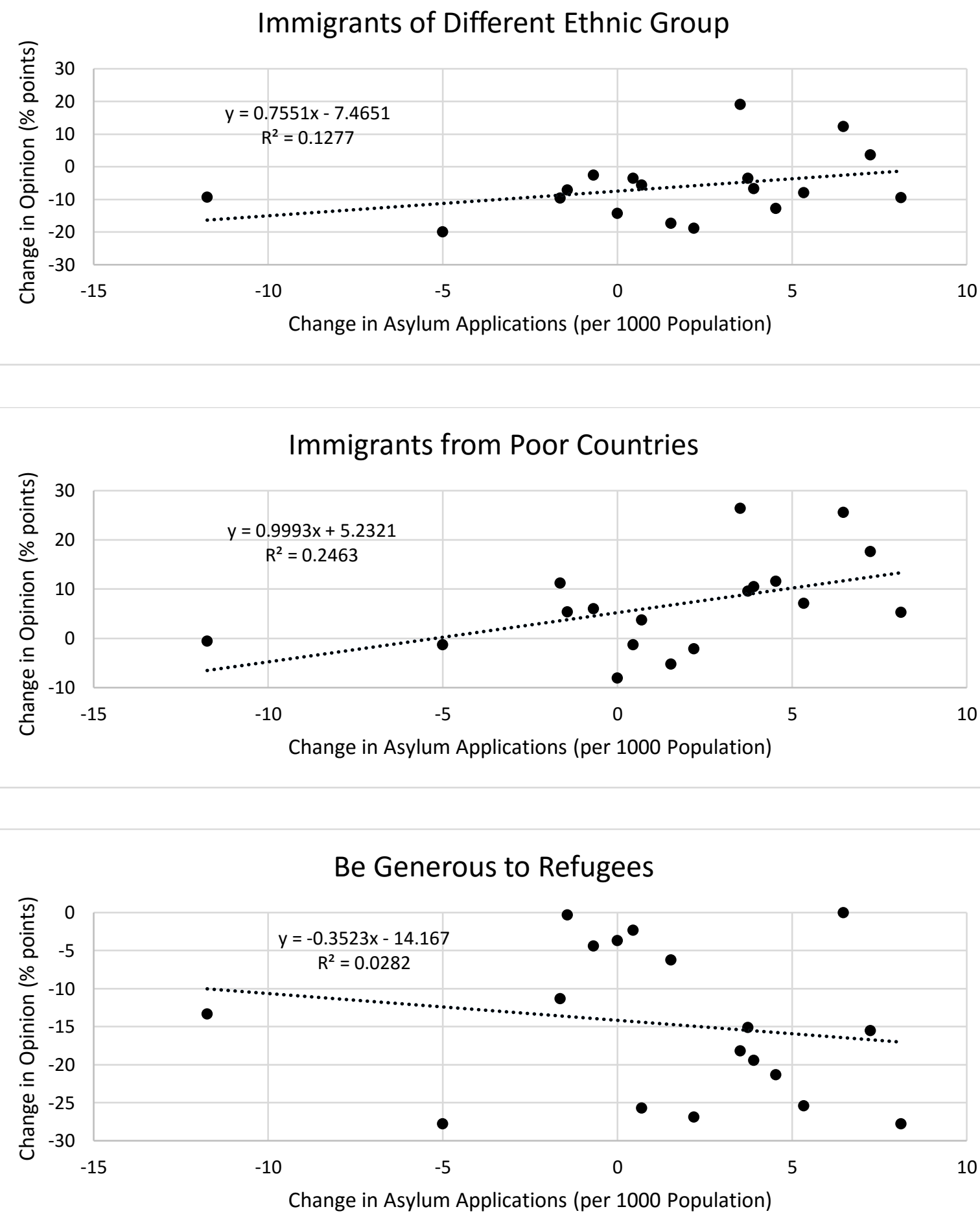